Article

\title{
Do Countries Use Foreign Aid to Buy Geopolitical Influence? Evidence from Donor Campaigns for Temporary UN Security Council Seats
}

\author{
Bernhard Reinsberg \\ School of Social and Political Sciences, University of Glasgow, Glasgow, G12 8RT, UK; \\ E-Mail: bernhard.reinsberg@glasgow.ac.uk
}

Submitted: 21 November 2018 | Accepted: 18 January 2019 | Published: 5 June 2019

\begin{abstract}
In recent years, donor countries have increasingly used different aid allocation channels to boost aid effectiveness. One delivery channel that has grown tremendously is 'multi-bi aid'-contributions to multilateral organizations earmarked for specific development purposes. This article examines whether donors use multi-bi aid to further their selfish goalsspecifically, to garner political support for their ambition to become a temporary member of the UN Security Council. In this context, multi-bi aid is particularly beneficial to countries with limited experience as foreign aid donors; whose governance quality is weak; and which are more internationalized. Using a sample of OECD/DAC donor countries in 1995-2016, time-series cross-section analysis corroborates these arguments. The analysis draws on a new dataset of media reports proxying for donor interest in winning a temporary seat in the UN Security Council and extended data on multi-bi aid flows. The findings demonstrate that multi-bi aid may be a tool for geopolitical influence, with yet unexplored consequences for aid effectiveness.
\end{abstract}

\section{Keywords}

donor interest; earmarked funding; foreign aid; multi-bi aid; UN Security Council

Issue

This article is part of the issue "Aid Impact and Effectiveness", edited by Rachel M. Gisselquist and Finn Tarp (UNU-WIDER, Finland).

(C) 2019 by UNU-WIDER; licensee Cogitatio (Lisbon, Portugal). This article is licensed under a Creative Commons Attribution 4.0 International License (CC BY).

\section{Introduction}

A growing body of work demonstrates that donor motivations matter for aid effectiveness (Dreher \& Kilby, 2010; Dreher, Klasen, Vreeland, \& Werker, 2013; Headey, 2008). Many observers infer donor motivations from different aid channels, arguing that bilateral aid advances selfish goals, while multilateral aid promotes collective goals by helping donors coordinate aid efforts, enhancing the credibility of aid commitments, and exploiting the expertise of multilateral bureaucracies (Hawkins, Lake, Nielson, \& Tierney, 2006).

The traditional distinction between bilateral aid and multilateral aid, however, is no longer tenable. Multibi aid-donor contributions to multilateral organizations earmarked for specific purposes-has emerged as a 'third way' of allocating foreign aid beside traditional channels (Reinsberg, 2017; Reinsberg, Michaelowa, \& Eichenauer, 2015; Reinsberg, Michaelowa, \& Knack, 2017). Inferring donor motivations is difficult for multibi aid because it combines motivational elements of both traditional modalities - the quest for control and the preference for cooperation.

Therefore, the motivations underlying multi-bi aid likely depend on additional circumstances. In some cases, multi-bi aid is purely developmental as donors use it to push multilaterals toward interventions yielding tangible results and efficiency-enhancing reforms (Reinsberg, 2017; Reinsberg et al., 2015; Sridhar \& Woods, 2013). In other cases-which are relatively underappreciated in the current literature-multi-bi aid may further the foreign policy goals of the donors.

As a test case for foreign-policy uses of multi-bi aid, I examine aid growth in the context of donor campaigns 
for a temporary seat in the United Nations Security Council (UNSC) - the only global institution to authorize the use of force and as such an important venue for wielding policy influence. Donor countries may therefore use foreign aid to win support for their UNSC campaign among UN member states. However, not all aid types are equally beneficial and uniformly available to all donors. In particular, donor countries with less experienced aid agencies are unable to muster capacities for short-term aid increases and should therefore be particularly likely to increase multi-bi funding, as a sufficiently targeted and quickly disbursable aid channel. Furthermore, donors with weak governance should use multi-bi aid to advance their UNSC campaign, as bilateral assistance would raise public concerns about non-development uses of aid. Finally, multi-bi aid provides internationally-oriented donors with an instrument to undergird their preference for international cooperation while creating the regional co-benefits that multilateral aid is unlikely to provide.

I test my theoretical arguments using data for up to 35 Organization for Economic Cooperation and Development (OECD)/Donor Assistance Committee (DAC) donor countries over 1995-2016. I analyze whether the campaign activity of a donor for a temporary UNSC seat predicts contemporaneous aid increases. I proceed with fixed-effect linear panel regressions. In further analysis, I also take potential endogeneity of campaigning with respect to aid growth into account. In both cases, I find that donors support UNSC campaigns with multi-bi aid specifically when their own aid agencies are less experienced, when their governance frameworks are weak, and when they are more internationalized. To demonstrate the plausibility of these findings, I provide quotes from interviews with government officials.

My study contributes to the literature on the political economy of international organizations and aid allocation. Within the broad literature on the UNSC (e.g., Malone, 2000; Mikulaschek, 2018; Prantl, 2005; Voeten, 2001; Vreeland \& Dreher, 2014a), some research focuses on who gets elected to the institution (Dreher, Gould, Rablen, \& Vreeland, 2014; Schmitz \& Schwarze, 2012; Vreeland \& Dreher, 2014b), whereas other research explicitly links aid allocation and multilateral lending decisions to temporary UNSC membership of recipient countries (Dreher, Lang, Rosendorff, \& Vreeland, 2018; Dreher, Sturm, \& Vreeland, 2009; Kuziemko \& Werker, 2006; Lim \& Vreeland, 2013; Vreeland \& Dreher, 2014a). In contrast to these studies, I focus on the strategies that donors use to enhance their chances of getting themselves elected to the institution.

In addition, I complement existing research on the determinants of multi-bi aid (Eichenauer \& Reinsberg, 2017). My analysis establishes conditions under which multi-bi aid is attractive for geopolitical purposes, as the posited effect is only present for small donors without entrenched aid bureaucracies. By focusing on one specific aspect of geostrategic use of aid, I extend previous aid allocation research, which often uses broad proxies for donor interest (Alesina \& Dollar, 2000; Berthélemy, 2006; Hoeffler \& Outram, 2011). Indeed, the rise of multibi aid has created new avenues for donor influencewith yet unknown consequences for aid effectiveness. Previous research suggests that geopolitically motivated aid is less effective, for instance due to sloppier project preparation under time pressure, the approval of lowerquality projects, and lower compliance with conditionality (Dreher et al., 2013; Kilby, 2013; Stone, 2009). Whether this holds also for multi-bi aid is an open question though, given that donor motivations cannot easily be inferred for this type of aid.

\section{Argument}

Countries vie for UNSC membership for three main reasons: gaining international prestige and reputation for being a responsible nation in the pursuit of global peace; advancing the national position on an upcoming issue; and promoting broader objectives and collective norms (Malone, 2000, pp. 6-7). Official statements reflect that developed countries consider UNSC membership to be valuable to them. For instance, a Canadian representative, leading his country toward a bid for a nonpermanent seat in 2011-12, argued, "[g]enerally speaking, you can see that the big issues do get discussed at the UN Security Council...[w]hen you take yourself out of that game, you lose one of the vehicles you have for having some influence" (The Canadian Press, 2014). In an earlier bid, Canada had announced to use the influence afforded by a UNSC seat to promote "human security," following up on its earlier success in pushing for an anti-personnel landmine convention and the International Criminal Court (Malone, 2000, p. 7).

The UNSC consists of the five permanent members (P5)-China, France, Russia, the United Kingdom, and the United States-and ten non-permanent members which are elected in periodic ballots at the UN General Assembly (UNGA) to serve two-year tenures. Besides "contributions to the maintenance of international peace" (United Nations, 1945, art. 23), the UN Charter requires equitable geographical representation of nonpermanent members, which is ensured by allotting the temporary seats to five regional groups in the following manner: three seats for the African group, two seats for the Asia-Pacific group (APG), two seats for the Latin American and Caribbean states group (GRULAC), one seat for the Eastern European group (EEG), and two seats for the Western European and Others Group (WEOG). ${ }^{1}$ Half of the temporary seats are up for grabs each year, which implies different schedules of UNGA elections across caucus groups. Every even year, two seats for WEOG, one for the APG, one for GRULAC, and one for the African Group come up for election, whereas every odd year, states vie for two seats for the African Group, one for the APG, one for the EEG, and one for GRULAC.

\footnotetext{
${ }^{1}$ According to a gentlemen agreement, Africa and Asia make available one seat for an Arab country in alternating order.
} 
The selection of the non-permanent UNSC members follows a two-stage process. First, countries selfnominate for candidacy in their respective regional group. They simply declare their candidacy to their regional chair in New York, which then adds the country to the list of candidates (Security Council Report, 2009, p. 9). Most candidates inform UN members of their candidacy afterwards. While some regional groups have established informal practice of rotation-based nominations, other groups have no established procedures to coordinate the nomination process. In the former groups, the sole candidate for an open seat typically has regional endorsement. In the latter groups, however, competition for seats is intense, as the number of candidates exceeds the number of available seats. For example, WEOG follows an "open-market practice" (Malone, 2000, p. 5) in which members compete over seats freely. For example, the current WEOG seats are split among three countries-Sweden for a full tenure and Italy and the Netherlands serving subsequent oneyear terms (United Nations, 2016). As a result, countries aspiring for UNSC membership have come to announce their candidature far in advance, in the hope to remain uncontested. For example, Switzerland has announced its candidature for 2023-24 in 2011 (Federal Department of Foreign Affairs, 2018). Competition for the Eastern European seat is similarly high. Contested ballots are not uncommon: 9 out of the 12 elections in 1990-2015 were initially contested. For example, four countriesArmenia, Azerbaijan, Hungary, and Slovenia-declared interest to represent the region in 2012-13, but given regional pressures to avoid contested elections, several countries dropped their aspirations later in the process.

Following the nomination phase, the UN member states vote for candidates in the UNGA. The election is a secret ballot and a candidate requires two-third majority approval of all countries participating in the ballot in order to be elected as temporary UNSC member. If no candidate obtains the required majority, run-off votes continue until one of the candidates is elected. UNGA elections typically take place in the last quarter of a year, with new tenures beginning in the first month of the subsequent year. After a country has served its two-year term in the UNSC, it cannot immediately re-apply for candidature for two years (United Nations, 1945, art. 23).

To further their chances of election for a temporary UNSC seat, states recur to several tools of foreign policy. Based on an inductive analysis of media reports of UNSC candidates, I have identified at least four such tools. First, states can win over other UN members by rhetorically supporting policy positions that are important to them. For example, the Czech Republic, vying for the 2008-09 Eastern European seat, also claimed by Croatia, attempted to win the votes of Morocco by shunning the cartoons of the prophet Mohammed (CTK Daily News, 2006). Second, states can mutually support candidatures for lucrative posts in international bodies.
Support for a UNSC bid may be reciprocated by later support for candidature in another international organization. Australia provides an example, which secured support for its 2013-14 bid from Rwanda in exchange for supporting Rwanda in its membership application to the Commonwealth (BBC Monitoring Africa, 2009). Third, states can curry favor by promising an expansion of bilateral trade and foreign direct investment. For instance, Japan committed to have its businesses invest USD 5.7 billion in infrastructure projects in Bangladesh, while winning support for its bid for a temporary seat on the UNSC (Reuters, 2014).

Fourth, states can use foreign aid to persuade other countries to vote for them in a UNGA ballot. Although aid-giving - in contrast to the previous tools-is limited to less developed countries, it is relatively more common. Descriptive analysis of media reports on UNSC campaigns over the past 20 years - available from Factivayields 15 news reports that explicitly mention pledges of aid in the context of UNSC candidatures-either generally to specific causes, or (more commonly) to specific countries. Ten pledges were from WEOG states, 4 from Asian-Pacific states, and one from the EEG. Obviously, this is merely a lower bound of the true extent of the phenomenon, given that some aid may be given privately in an expectation for votes in return. In contrast, the data entail only 12 new reports in which deeper economic cooperation was offered (explicitly) - six by WEOG donors, three by the APG, one from EEG, and two from GRULAC.

\subsection{Can Aid Buy Support for UNSC Candidatures?}

Donors can further their chances of winning a temporary seat by increasing foreign aid, especially to poorer countries, which depend on foreign aid for economic development and which may be willing to support a donor vying for a seat in return for aid-an important example of an "aid-for-policy deal" (Bueno de Mesquita \& Smith, 2009). ${ }^{2}$ Some donors are open about how aid supports their foreign policy goals, especially in contested races. For example, the foreign affairs minister of a small donor said:

The main thing is: Do we get a return on that investment? Given what we spend on the Commonwealth, and campaigning for a seat on the Security Council, this is just one more opportunity to engage with leaders of other countries and convince them to support New Zealand.

The country paid almost USD 1 million to the Commonwealth secretariat in 2011-12 and provided technical assistance over USD 4 million to Commonwealth countries, while seeking support for its bid for temporary UNSC membership (Dominion Post, 2003).

Whereas more aid can increase the chances of winning, less aid can decrease them-an unpleasant lesson

\footnotetext{
${ }^{2}$ These deals occur because developing countries are assumed to care more about material benefits than (most) policy issues given their low income.
} 
learnt by Australia, Iceland, Spain, and Sweden. For instance, when Iceland was hit by the Global Financial Crisis in 2008, its chances for the 2009-10 spot for which it had vied were hurt according to Western diplomats (CNN, 2008). Concerns were also growing in Spain that the stagnating aid budget-a result of the Global Financial Crisis-would adversely affect the chances of winning a UNSC seat in 2015-16. In Sweden, where pressures on aid budgets mounted due to refugee costs, similar concerns were raised (Jacobsen, 2015). The above discussion implies the following hypothesis:

Hypothesis 1: Donors will increase foreign aid to advance their campaigns for a temporary UNSC seat.

\subsection{Choice of Aid Channels}

Donors face a decision of which aid channel to use for advancing their UNSC campaign. The decision to alter the distribution of aid across delivery channels may be particularly important if the donor is unable to increase total aid. First, a donor can use bilateral aid, which is typically given to a recipient government. It is attractive to both sides as it furthers the foreign policy goal of the donor while being valuable to the recipient government, especially if provided as general budget support. In contrast, multilateral aid involves the pooling of resources among several donors and delegation to a multilateral aid agency that uses the funds at its own discretion. By diluting the influence of any individual donor and due to its long commitment cycles, multilateral aid is unlikely to be used for buying support for UNSC candidatures. Finally, multi-bi aid-donor contributions to multilateral organizations earmarked for specific development purposes-affords donors a third channel of aid delivery. It is a flexible mechanism whereby donors can support specific regions, countries, themes, or sectors through special funds, whose aid allocation decisions are not generally overseen by the formal governing bodies of the host multilaterals. For instance, Australia took advantage of this flexibility and provided multi-bi aid through a UN organization to garner support for its UNSC campaign in Ethiopia (Australian Associated Press, 2008).

Not all aid channels are equally attractive to all donors and under all circumstances given that donors vie for a temporary UNSC seat. Focusing on multi-bi aid, I derive three hypotheses on when this channel is particularly attractive. First and foremost, I expect donors with limited experience and thus capacity to stem shortterm aid increases to be particularly likely to increase multi-bi aid to support their UNSC campaign. To these donors, multi-bi aid is the only way to direct funding that is sufficiently targeted and quickly disbursable. Alternative channels are not appropriate: While multilateral aid cannot be targeted, bilateral aid is not a feasible option due to capacity limitations that these donors face. An observable implication is that experienced donors are more likely to use bilateral aid in support of a UNSC campaign.
Hypothesis 2: As donor experience increases, a donor will increase bilateral aid but decrease multi-bi aid in the context of a UNSC campaign.

Second, donors with relatively higher levels of domestic corruption are more likely to use multi-bi aid. A sizeable literature argues that donor characteristics not only matter for aid effectiveness (Bourguignon \& Sundberg, 2007; Dreher \& Kilby, 2010; Wright \& Winters, 2010) but also affect aid channel choices (Dietrich, 2013; Dietrich \& Wright, 2015; Reinsberg et al., 2017). Public opinion can constrain donor choices in that a more skeptical public forces donor governments to re-route larger shares of their aid budget through multilateral organizations which publics generally trust more to act as prodevelopment actors (Milner, 2006). Similarly, publics are easily alienated by aid fraud-whether in recipient countries (Bauhr, Charron, \& Nasiritousi, 2013) or in their own government, which implies that donor governments with weak governance may need to channel aid multilaterally to reassure domestic audiences of aid being well spent. An observable implication is that donors with "good governance" are more likely to use bilateral aid to support their campaigns.

Hypothesis 3: As governance quality increases, a donor will increase bilateral aid but decrease multi-bi aid in the context of a UNSC campaign.

Third, donor preferences for international cooperation matter. Some donors traditionally use aid more to advance narrow foreign policy goals (Bueno de Mesquita \& Smith, 2009), while others conceive aid as a vehicle to build partnerships and to demonstrate international solidarity (Lumsdaine, 1993). Sweden is an example of a country that embraces the latter view. Having faced skyrocketing domestic expenses due to the refugee crisis, the Swedish government needed to consider significant cuts to the aid budget in recent years. The Swedish foreign ministry wrote that in such an event Sweden would damage its reputation and that it "would also have to give up its candidacy for a seat in the United Nations Security Council, as [its] high development aid contribution is seen as its most important trump card" (Jacobsen, 2015). Hence, specifically donors with an ideological commitment to aid will use multi-bi aid if prompted by the opportunity to win a UNSC seat to increase overall aid. An observable implication is that less outwardoriented donors should prefer bilateral aid to advance their campaigns.

Hypothesis 4: As a donor becomes more internationalized, it will increase multi-bi aid but decrease bilateral aid in the context of a UNSC campaign.

In the empirical analysis, I also consider heterogeneous effects with respect to constituency. As sufficient timeseries information on aid flows is available only for states 
that report to the $O E C D$, specifically its $D A C$, I consider three constituencies-WEOG, EEG, and APG.

\section{Data and Methods}

I construct a panel dataset of initially 40 donors over the 1995-2016 period in the Northern hemisphere-23 WEOG donors, 12 EEG donors, and the two APG donors, Japan and Korea. Due to missing data, the panel is unbalanced. For three permanent UNSC members (France, United Kingdom, and the United States), the posited mechanism does not apply and I thus exclude these donors from the sample. The results are unchanged when including them nonetheless, as shown in a robustness test. ${ }^{3}$ I chose the sample period to allow for sufficient time after the dissolution of the Soviet Union and in view of concerns over data quality as some donors only then joined the OECD/DAC and began reporting their aid flows.

\subsection{Dependent Variables}

I disaggregate total aid into its three main channelsbilateral aid, multilateral aid, and multi-bi aid. I rely primarily on OECD/DAC data for that purpose (OECD, 2018). For multi-bi aid, OECD/DAC data only cover the 2006-16 period; to extend the time series to prior sample years, I rely on the multi-bi aid data (Eichenauer \& Reinsberg, 2017). The multi-bi aid data are available for $23 \mathrm{OECD} / \mathrm{DAC}$ donors and are based on the Creditor Reporting System, which ensures that both data sources are consistent. ${ }^{4}$ For each aid flow, I apply a logarithmic transformation to mitigate outliers. ${ }^{5}$ Using aid changes (rather than levels) helps de-trending the time series. This is also suggested by diagnostic tests. ${ }^{6}$ Furthermore, aid changes correspond closely to my theoretical interest in short-term effects. Following the aid allocation literature, I use aid commitments in constant USD in the main analysis (e.g., Dietrich \& Wright, 2015; Dreher, Langlotz, \& Marchesi, 2017; Hoeffler \& Outram, 2011), while using disbursements for robustness tests. Finally, in accordance with OECD/DAC definitions, aid flows do not include military aid, although military assistance was given once to support a UNSC campaign. ${ }^{7}$

\subsection{Predictors}

The key predictor of this study is the campaign activity for a temporary UNSC seat of a given donor in a given year. As no such indicator - to the best of my knowledge-was available, I sourced newspaper articles covering UNSC candidacies during 1994-2016 from Factiva. Appendix B explains the selection of media reports and the coding procedure in detail. The typical news article in my database is a statement of support by one country for the UNSC candidature of another country. I discarded duplicates (covering the same event) and campaigns for permanent memberships and UNSC reform. I then aggregated the data to the country-year format.

My main predictor-Campaign-is a binary indicator of whether there is at least one media report in which a donor is reported to bid for a temporary UNSC seat in a given year. The measure is not ideal, given that some donors may lobby non-publicly for seats and data sources are biased toward English-speaking outlets, but it successfully addresses the challenge that both the willingness to run for a seat and the timing of a campaign are otherwise unobservable. I also verify that donors release statements in close temporal proximity to their aspired tenure (Figure B1), with the mode of that distribution being one year prior.

To examine effect heterogeneity, I include multiplicative interaction terms between campaign activity and donor characteristics. To capture Donor Experience, I compute the natural logarithm of the difference $(t+1)-f$, where $f$ is the founding year of the (first) bilateral aid agency of a donor, and $t$ is the current year. For all sample years prior to foundation, I set its value to zero. For robustness tests, I use an alternative data source of the aid agency founding year (Fuchs \& Müller, 2018, p. 41). To measure donor governance, I use the ICRG Index of quality of government (The PRS Group, 2015), while using the VDem Corruption Index (Coppedge et al., 2016) for robustness. To measure preferences for cooperation, I use the Political Globalization index of the KOF institute (Dreher, 2006), which includes information on the number of embassies globally, active (I)NGOs, membership in international organizations, participation in peacekeeping missions, and treaties signed. In further analyses, I consider interactions of campaigns with binary indicators of three regional UN constituencies.

\subsection{Control Variables}

To mitigate the impact of potential confounders, I include several time-varying control variables. Without a mainstay model of donor-year aid growth at hand, I choose control variables with a view to maximize observations and thus the power of my statistical tests. First, macroeconomic shocks may affect the opportu-

\footnotetext{
${ }^{3}$ Excluding the P5 is consistent with the 'possibility principle' (Mahoney \& Goertz, 2004), because the purported mechanism is not applicable for these donors.

${ }^{4}$ Eichenauer and Reinsberg (2017) show that both datasets yield virtually identical aggregate multi-bi aid flows in 2006-12 and that the OECD/DAC data severely underreport multi-bi aid in earlier years. Any remaining discrepancies in aid levels are mitigated due to differencing.

${ }^{5}$ Specifically, $\ln (\Delta y)$ if $\Delta y \geq 0$ and $-\ln (-\Delta y)$ if $\Delta y<0$.

${ }^{6}$ Specifically, I conduct a Dickey-Fuller tests for stationarity for all transformed aid variables, rejecting the null hypothesis of unit roots in all panels $(p<1 E-4)$. A Wooldridge test indicates mild autocorrelation $(p<0.05)$, which can be remedied by including lagged levels of the dependent variable.

7 Based on publicly available media reports, Australia announced military assistance over approximately USD 4 million to the Philippines in 2009-10 (BusinessWorld, 2011).
} 
nity cost of aid provision and the willingness to campaign for a UNSC seat. I therefore include a binary indicator of financial crisis in the donor country (Laeven \& Valencia, 2013), as well as the percentage rate of GDP Growth. Second, domestic politics may affect aid policies and UNSC campaign decisions. For example, the Australian opposition leader Tony Abbott (Liberal party) challenged Kevin Rudd (Labor party) for his decision to run for a UNSC seat. Skeptical of foreign aid increases in general, Abbott promised to abandon the UNSC campaign and cut aid if elected prime minister (The Age, 2010). In other cases, governments may have avoided pursuing certain foreign policies as those policies were controversial among coalition parties. I therefore include binary indicators for Executive Elections, Left-wing government ideology, as well as a continuous measure of Government Fractionalization-all available from the Database of Political Institutions (Beck, Clarke, Groff, Keefer, \& Walsh, 2001).

All regressions further include country-fixed effects (accounting for unobserved heterogeneity) and yearfixed effects (accounting for common shocks). To control for donor size and mean reversion - the tendency of (stationary) variables to fluctuate around their average -1 include the log-transformed lagged value of the respective aid flow.

In robustness tests, I consider additional controls relating to events in the neighborhood of a donor countryfinancial crises, armed conflicts, and natural disasterswhich may prompt donors to reconsider aid policies and UNSC campaign decisions. For example, a donor may respond to emergent conflicts by providing more aid to address emergent needs while at the same time vying for more influence in the UNSC to help resolve these conflicts. I count the respective number of these types of events in all contiguous countries and neighboring countries no farther away than 1,500 kilometers and normalize by the total number of countries in the neighborhood to eliminate scaling effects.

Table 1 presents descriptive statistics and data sources for all variables. It shows that (non-P5) donors campaign for a temporary UNSC seat in around $6.4 \%$ of all years and $7.0 \%$ when excluding years of tenure and the two years following it. In addition, campaigning is widespread. The media reports identify 24 donors with at least one campaign in $1995-2016 .^{8}$ This represents $65 \%$ of all eligible donors. This ensures that results are unlikely to be driven by individual countries with frequent campaigns.

\subsection{Methods}

To adequately capture interdependencies across aid channels, I conduct seemingly unrelated regression (SUR) analysis. The SUR model controls for factors jointly affecting all aid channels by allowing for cross-equation correlations that appear as parameters in the crossequation variance-covariance matrix (Roodman, 2012). The model is especially suitable under the assumption of a fixed aid budget, implying that donors which want to boost one type of aid must decrease another type of aid to not overspend the budget. Even if aid budgets are freely determined, SUR estimates are consistent (albeit not necessarily efficient). Finally, I cluster standard errors by country, thereby mitigating temporal auto-correlation.

\section{Results}

\subsection{Correlational Analysis}

I examine the unconditional relationship between UNSC campaigning and aid growth graphically. The full regression results are available in the supplemental appendix but I do not show them here as I do not find a statistically significant unconditional relationship for various sets of control variables and measures of campaigning.

Figure 1 shows for all donors vying for a temporary UNSC seat the evolution of their total aid in a time window around the respective UNGA election. Each point shows for a given campaign for each year relative to the UNGA election ( $x$-axis) the logged absolute amount of aid dollars by which a donor has increased (or decreased) aid with respect to the previous year ( $y$-axis). The solid line is the average aid change across all campaigning donors, along with the $95 \%-\mathrm{Cl}$. I find no statistically significant change in aid growth, as the confidence intervals include zero.

Figure 2 tracks aid growth around UNGA elections separately for different aid channels. Multi-bi aid growth accelerates in the year before the UNGA election, but this finding does not hold in multivariate analysis, as shown in the appendix. For the remaining aid channels, there is no statistically significant growth effect in the context of UNSC campaigning. A possible interpretation is that donors are heterogeneous in the ways they use the various aid channels to support their UNSC candidature, which I will explore now.

Table 2 presents estimation results for the relationship between campaigning for a temporary UNSC seat and aid growth under different donor characteristics. I present results for all three estimating equations as a stacked vector, using a baseline set of control variables and referring to the supplemental appendix for robustness to other controls.

In Model 1, I find a marginally significant effect in the difference of campaign effects between experienced donors and inexperienced donors. For multi-bi aid, I find the effect to be in the expected direction, but not statistically significant. For bilateral aid, everything else equal, 25 years of donor experience are related to an increase in bilateral aid growth by about USD 200,000-compared

\footnotetext{
${ }^{8}$ These donors include: Australia, Azerbaijan, Bulgaria, Canada, Croatia, Czech Republic, Denmark, Finland, Greece, Iceland, Israel, Ireland, Italy, Japan, Korea, Lithuania, Norway, New Zealand, Poland, Romania, Slovak Republic, Slovenia, Spain, and Turkey.
} 
COGITATIO

Table 1. Descriptive statistics and variable definitions.

\begin{tabular}{|c|c|c|c|c|c|c|}
\hline & Observations & Mean & Sd & Min & Max & Description \\
\hline \multicolumn{7}{|l|}{ Dependent variables } \\
\hline Bilateral aid growth & 567 & 2.24 & 18.35 & -22.08 & 22.59 & $\begin{array}{l}\ln \left(B_{i t}-B_{i, t-1}+e\right) \text { if } B_{i t}-B_{i, t-1} \geq 0,-\ln \left(-\left[B_{i t}-B_{i, t-1}\right]\right) \text { otherwise; } B_{i t} \text { refers to bilateral ODA net of multi-bi } \\
\text { aid, sourced from Table DAC1 (OECD, 2018); } e \text { is an offset to ensure a non-missing value if growth is zero }\end{array}$ \\
\hline Multilateral aid growth & 567 & 2.31 & 17.81 & -21.57 & 21.58 & $\begin{array}{l}\ln \left(M_{i t}-M_{i, t-1}+e\right) \text { if } M_{i t}-M_{i, t-1} \geq 0,-\ln \left(-\left[M_{i t}-M_{i, t-1}\right]\right) \text { otherwise; } M_{i t} \text { refers to multilateral ODA, } \\
\text { sourced from Table DAC1 (OECD, 2018) }\end{array}$ \\
\hline Multi-bi aid growth & 420 & 2.65 & 17.04 & -22.13 & 22.17 & $\begin{array}{l}\text { In }\left(M B_{i t}-M B_{i, t-1}+e\right) \text { if } M B_{i t}-M B_{i, t-1} \geq 0,-\ln \left(-\left[M B_{i t}-M B_{i, t-1}\right]\right) \text { otherwise; } M B_{i t} \text { refers to multi-bi aid, } \\
\text { sourced from Table DAC1 for 2006-16 (OECD, 2018) and from the multi-bi aid data for 1990-12 } \\
\text { (Eichenauer \& Reinsberg, 2017) }\end{array}$ \\
\hline
\end{tabular}

\section{Key predictor}

Campaign

$999 \quad 0.06 \quad 0.24$

$0.00 \quad 1.00$

\section{Control variables}

Financial crisis

GDP growth (\%)

Executive election

Left-wing government

Regional financial crises

$$
918
$$

918

$0.35 \quad 0.27$

$0.00 \quad 1.00$
- Binary indicator for Media Reports $>0$ (the procedure for identifying media reports on temporary UNSC seat campaigns is laid out in Appendix B), coded from Factiva

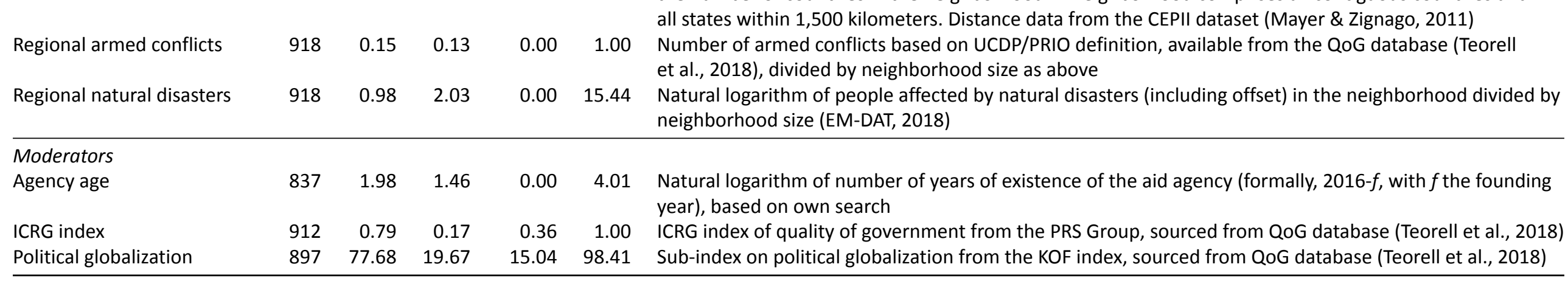

$0.00 \quad 0.83$ Government fractionalization is defined as the probability that any two legislators are not from the same

$0.001 .00 \quad \begin{aligned} & \text { Number of financial crises (Laeven \& Valencia, 2013) in the neighborhood of a donor country, divided by } \\ & \text { party, from the Database of Political Institutions, sourced from QoG database (Teorell et al., 2018) }\end{aligned}$ the number of countries in the neighborhood. A neighborhood comprises all contiguous countries and all states within 1,500 kilometers. Distance data from the CEPII dataset (Mayer \& Zignago, 2011)

1.00 Binary indicator for (contemporaneous) incidence of financial crisis (Laeven \& Valencia, 2013) (Teorell et al., 2018)

B.00 Binary indicator for (contemporaneous) executive election from the Database of Political Institutions, sourced from QoG database (Teorell et al., 2018)

Binary indicator for left-wing government (largest governing party or the state executive-depending on the political system), from the Database of Political Institutions, sourced from QoG database on the political system), from the Database of Political Institutions, sourced from QoG database

$0.11 \quad 0.00 \quad 1.00$

Politics and Governance, 2019, Volume 7, Issue 2, Pages 127-154 


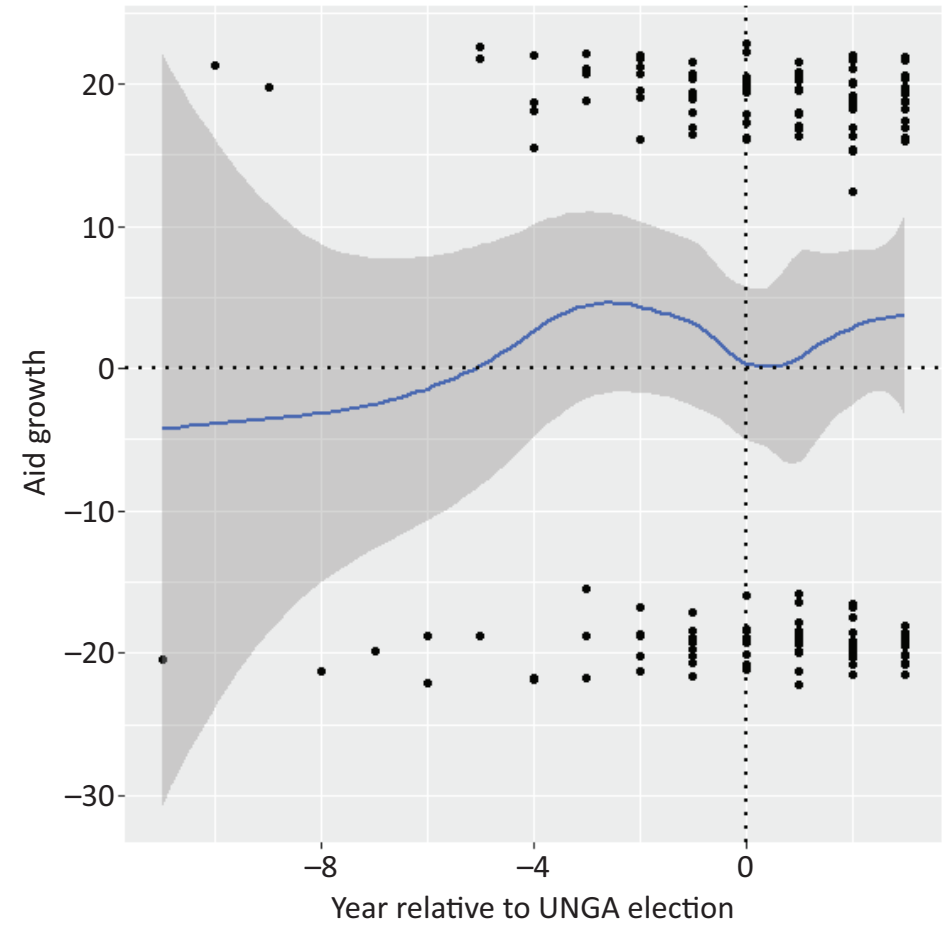

Figure 1. Absolute aid growth in the context of UNSC campaigns. Note: UNSC campaign start year is endogenously determined by the first media report, whereas the figure tracks aid growth up to three years after the UNGA election year.
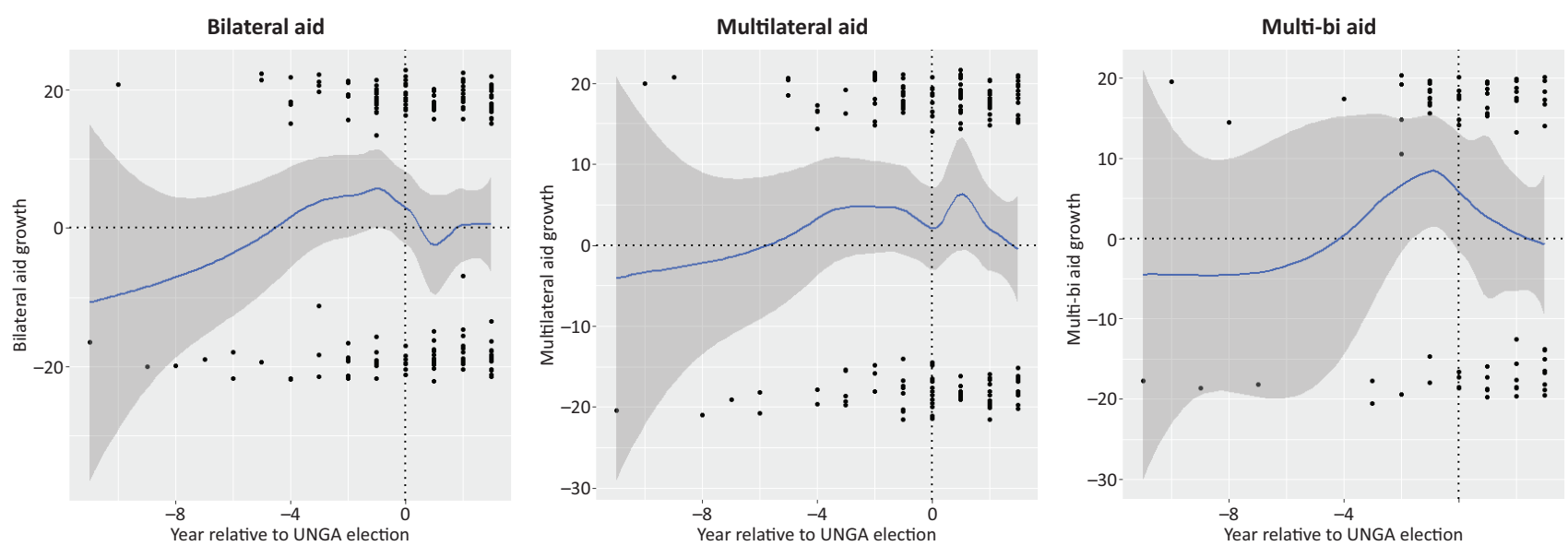

Figure 2. Absolute aid growth in the context of UNSC campaigns for different aid channels. Note: UNSC campaign start year is endogenously determined by the first media report, whereas the figure tracks aid growth up to three years after the UNGA election year.

to a fully inexperienced donor-in the context of a UNSC campaign $(p<0.1){ }^{9}$ Figure 3 plots the marginal effect of campaigning on bilateral aid growth conditional on logged years of donor experience. Consistent with theoretical expectations, the marginal effect of campaigning on bilateral aid growth increases with donor experience and becomes positively significant only for the most experienced donor.

Model 2 explores the moderating impact of donor governance. Specifically, decreases in governance quality let donors increase their multi-bi aid growth to support a UNSC campaign. Above the mean of governance quality, the effect of UNSC campaigning on multi-bi aid growth is not statistically significant, but the effect increases and becomes positively significant at lower governance values. For example, multi-bi aid growth increases by about USD 15,000 when reducing governance quality by one standard deviation $(\sigma=0.17)$. Figure 4 shows the conditional marginal effect across the entire range of governance quality.

In Model 3, I find that political globalization is significantly related to an acceleration of campaign-induced multi-bi aid growth. As the globalization index is never zero for any donor, the effect is best illustrated in an in-

\footnotetext{
${ }^{9}$ Multiply $\ln (25)$ with $\beta=3.807$ and exponentiate the result.
} 
Table 2. UNSC campaign and aid growth with basic control variables.

\begin{tabular}{|c|c|c|c|c|c|c|}
\hline \multirow[b]{2}{*}{ Bilateral aid growth } & \multicolumn{2}{|c|}{$\begin{array}{l}\text { Donor experience } \\
\text { (1) }\end{array}$} & \multicolumn{2}{|c|}{$\begin{array}{l}\text { Governance quality } \\
\text { (2) }\end{array}$} & \multicolumn{2}{|c|}{$\begin{array}{l}\text { Political globalization } \\
\text { (3) }\end{array}$} \\
\hline & & & & & & \\
\hline Campaign & -8.093 & $(6.285)$ & -2.378 & $(18.218)$ & -0.336 & $(41.956)$ \\
\hline Campaign $\times X$ & $3.807^{*}$ & $(2.208)$ & 5.376 & $(21.474)$ & 0.019 & $(0.488)$ \\
\hline $\mathrm{x}$ & 0.277 & $(1.950)$ & 11.556 & $(19.876)$ & 0.110 & $(0.294)$ \\
\hline Financial crisis & $-10.045^{* *}$ & $(4.637)$ & $-10.387 * *$ & $(4.643)$ & $-9.436 * *$ & (4.631) \\
\hline GDP growth & 0.222 & $(0.439)$ & 0.190 & $(0.444)$ & 0.570 & $(0.527)$ \\
\hline Executive election & -3.884 & $(3.574)$ & -4.477 & $(3.487)$ & -3.958 & (3.580) \\
\hline Left-wing government & 0.583 & $(1.897)$ & 0.717 & $(1.849)$ & 1.001 & (1.890) \\
\hline Government fractionalization & -4.141 & $(5.357)$ & -4.306 & $(5.332)$ & -3.059 & $(5.671)$ \\
\hline Lagged aid level & $-15.816^{* * *}$ & $(1.734)$ & $-16.053^{* * *}$ & $(1.717)$ & $-17.707^{* * *}$ & $(1.997)$ \\
\hline \multicolumn{7}{|l|}{ Multilateral aid growth } \\
\hline Campaign & -8.815 & $(8.696)$ & 4.789 & $(23.410)$ & $-65.591^{*}$ & $(37.205)$ \\
\hline Campaign $\times X$ & 2.676 & $(2.860)$ & -6.941 & $(26.743)$ & 0.749* & $(0.433)$ \\
\hline $\mathrm{x}$ & 2.677 & $(1.997)$ & -17.106 & $(22.132)$ & 0.115 & $(0.289)$ \\
\hline Financial crisis & 2.782 & $(5.385)$ & 3.113 & $(5.292)$ & 2.995 & (5.389) \\
\hline GDP growth & $0.584 * *$ & $(0.279)$ & $0.567^{* *}$ & $(0.279)$ & $0.622^{*}$ & $(0.324)$ \\
\hline Executive election & -3.891 & (3.810) & -4.256 & $(3.741)$ & -4.232 & (3.670) \\
\hline Left-wing government & 1.548 & $(1.781)$ & 2.258 & $(1.766)$ & 2.309 & $(1.804)$ \\
\hline Government fractionalization & 1.798 & $(5.350)$ & 1.779 & (5.483) & 1.670 & (5.872) \\
\hline Lagged aid level & $-13.512^{* * *}$ & $(2.007)$ & $-13.242^{* * *}$ & $(1.941)$ & $-13.719 * * *$ & $(2.037)$ \\
\hline \multicolumn{7}{|l|}{ Multi-bi aid growth } \\
\hline Campaign & 1.316 & $(9.406)$ & $51.894 * * *$ & $(18.888)$ & $-141.226 * * *$ & $(53.114)$ \\
\hline Campaign $\times X$ & 0.483 & (3.059) & $-56.127^{* *}$ & $(22.490)$ & $1.590 * * *$ & $(0.603)$ \\
\hline $\mathrm{x}$ & $-3.518^{*}$ & $(2.084)$ & -19.821 & $(24.171)$ & 0.055 & $(0.440)$ \\
\hline Financial crisis & -3.709 & $(3.283)$ & -3.496 & (3.367) & -1.940 & (3.727) \\
\hline GDP growth & 0.510 & $(0.404)$ & 0.495 & $(0.408)$ & 0.241 & $(0.460)$ \\
\hline Executive election & 6.248 & $(4.079)$ & 6.135 & $(3.868)$ & 6.420 & (4.071) \\
\hline Left-wing government & 1.373 & $(1.961)$ & 0.759 & $(1.917)$ & 1.244 & (1.960) \\
\hline Government fractionalization & 4.667 & (7.994) & 2.978 & (7.995) & 7.451 & (8.316) \\
\hline Lagged aid level & $-4.481 * * *$ & $(0.746)$ & $-4.251 * * *$ & $(0.716)$ & $-4.099 * * *$ & $(0.719)$ \\
\hline Country-fixed effects & yes & & yes & & yes & \\
\hline Year-fixed effects & yes & & yes & & yes & \\
\hline$N_{B} / R_{B}^{2}$ & 481 & 0.25 & 481 & 0.24 & 452 & 0.25 \\
\hline$N_{M} / R_{M}^{2}$ & 481 & 0.23 & 481 & 0.23 & 452 & 0.22 \\
\hline$N_{M B} / R_{M B}^{2}$ & 383 & 0.24 & 383 & 0.24 & 354 & 0.25 \\
\hline$\rho_{B, M}$ & 0.028 & $(0.046)$ & 0.032 & $(0.046)$ & 0.027 & $(0.048)$ \\
\hline$\rho_{B, M B}$ & 0.004 & $(0.053)$ & 0.005 & $(0.053)$ & -0.024 & $(0.054)$ \\
\hline$\rho_{M, M B}$ & 0.067 & $(0.054)$ & 0.068 & $(0.054)$ & 0.062 & $(0.056)$ \\
\hline
\end{tabular}

Notes: System of equations estimated simultaneously with dependent variables shown in row heads. Campaign is a binary indicator, $X$ is the moderator in the respective column header, and Campaign $\times X$ the multiplicative interaction term. Abbreviations in the diagnostics section refer to the number of observations across bilateral aid $\left(N_{B}\right)$, multilateral aid $\left(N_{M}\right)$, and multi-bi aid $\left(N_{M B}\right)$, R-squared, and cross-equation correlations, respectively. Significance levels: ${ }^{*} p<.1 * * p<.05 * * * p<.01$.

teraction plot. Figure 5 shows that the campaign effect is positively significant only for the most globalized donors, insignificant for the average donor, and negatively significant for inward-oriented donors. Substantively, if political globalization is increased by one standard deviation ( $\sigma=9.02$ ), multi-bi aid growth accelerates by more than USD 1.7 million ( $p<0.01$ ), while multilateral aid increases by a meager USD $867(p<0.1)$ in the context of a UNSC campaign.
While the effects of most control variables remain statistically insignificant, they point into the expected direction. Among the statistically significant controls, I find that financial crises negatively affect bilateral aid growth $(p<0.05)$ and that more experienced donors tend to mobilize larger increases of bilateral aid $(p<0.1)$. For multilateral aid, I find a significantly positive relationship between GDP growth and multilateral aid growth $(p<0.1)$. For multi-bi aid, none of the controls has a significant ef- 


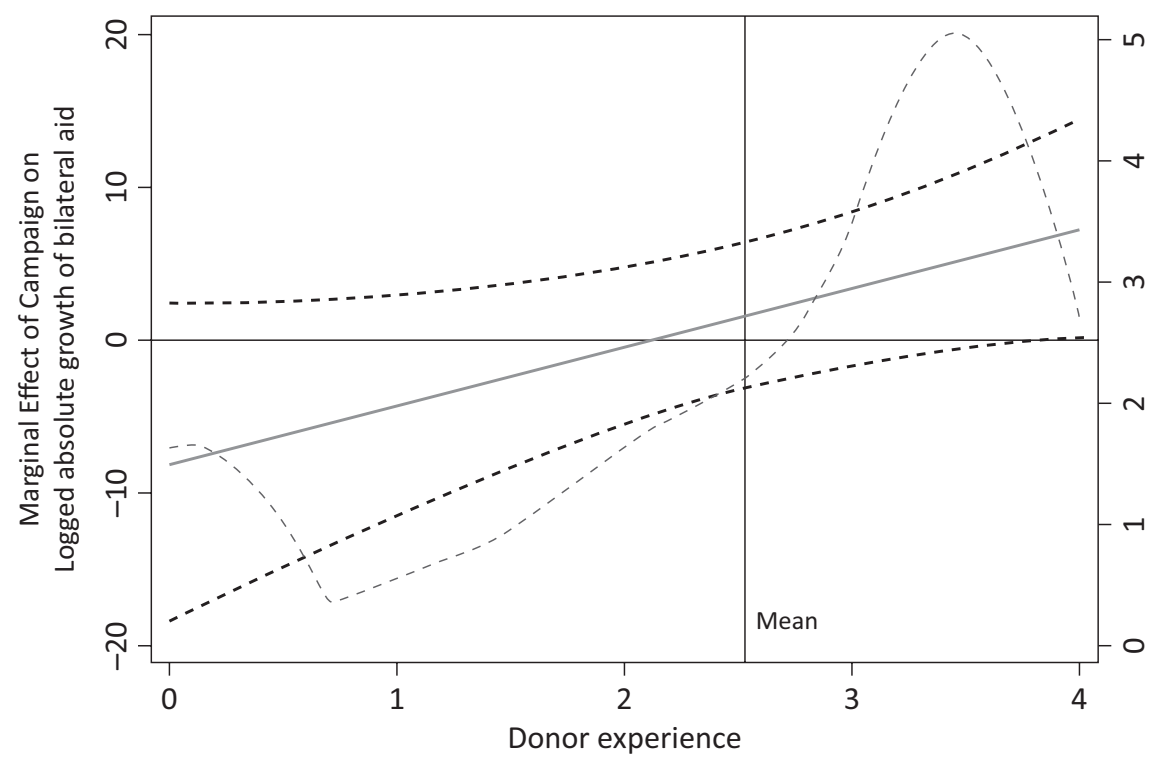

Thick dashed lines give $90 \%$ confidence interval.

Thin dashed line is a kernel density estimate of donor experience.

Figure 3. Marginal effect of campaigns on multi-bi aid growth conditional on donor experience.

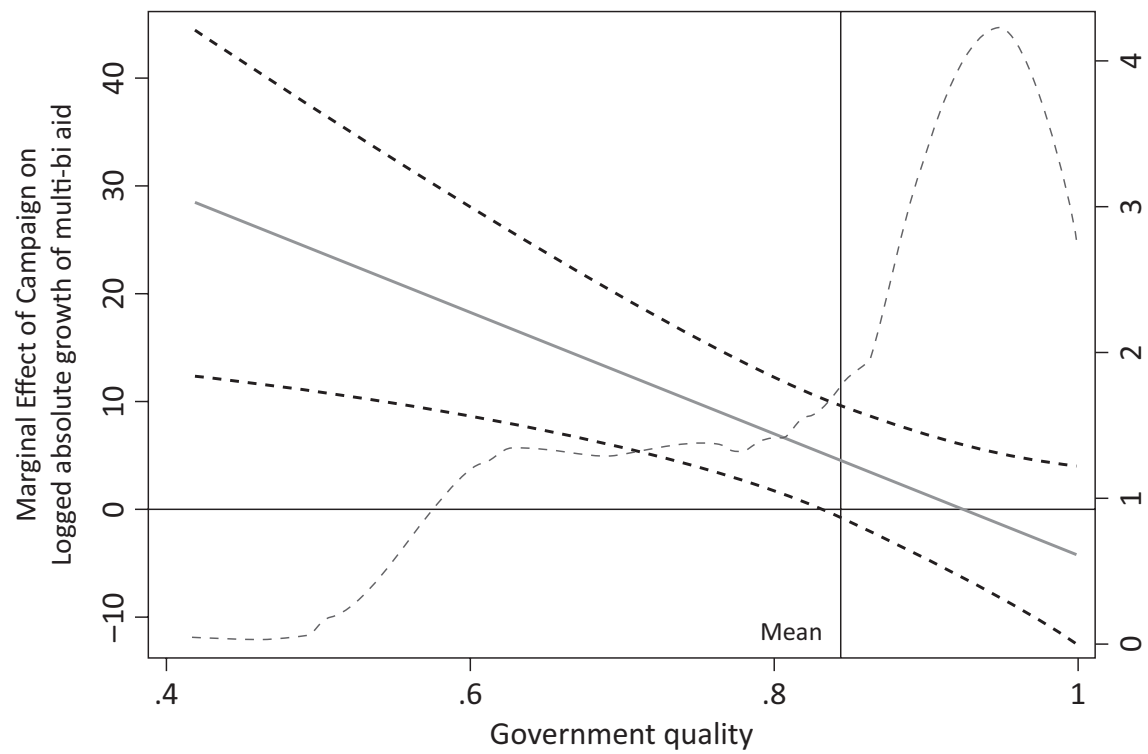

Thick dashed lines give $90 \%$ confidence interval.

Thin dashed line is a kernel density estimate of government quality.

Figure 4. Marginal effect of campaigns on multi-bi aid growth conditional on governance quality.

fect. In all equations, lagged aid levels have a statistically significant effect, indicating mean-reverting time series $(p<0.01)$. Overall, model specifications are plausible as the models explain more than $20 \%$ of the variation in all aid types. Thanks to joint estimation, I can assess the extent to which aid growth across different channels is correlated. The cross-equation correlations are insignificant in most regressions.

\subsection{Instrumental-Variable Design}

The results thus far are based on correlations. In the remainder, I consider potential endogeneity of campaign- ing with respect to aid growth. For example, donor preferences for aid provision and running for a seat may be affected simultaneously by unobserved factors. Therefore, I introduce an instrumental variable-the number of donors in the same constituency that are reported to vie for the same temporary UNSC seat as a given donor. This instrument fulfills the relevance criterion because a donor will need to do more campaigning if many other donors vie for the same spot. In addition, to the extent that peer campaigning affects donor-specific aid growth only through donor campaigning, the instrument fulfills excludability, conditional on control variables and fixed effects. 


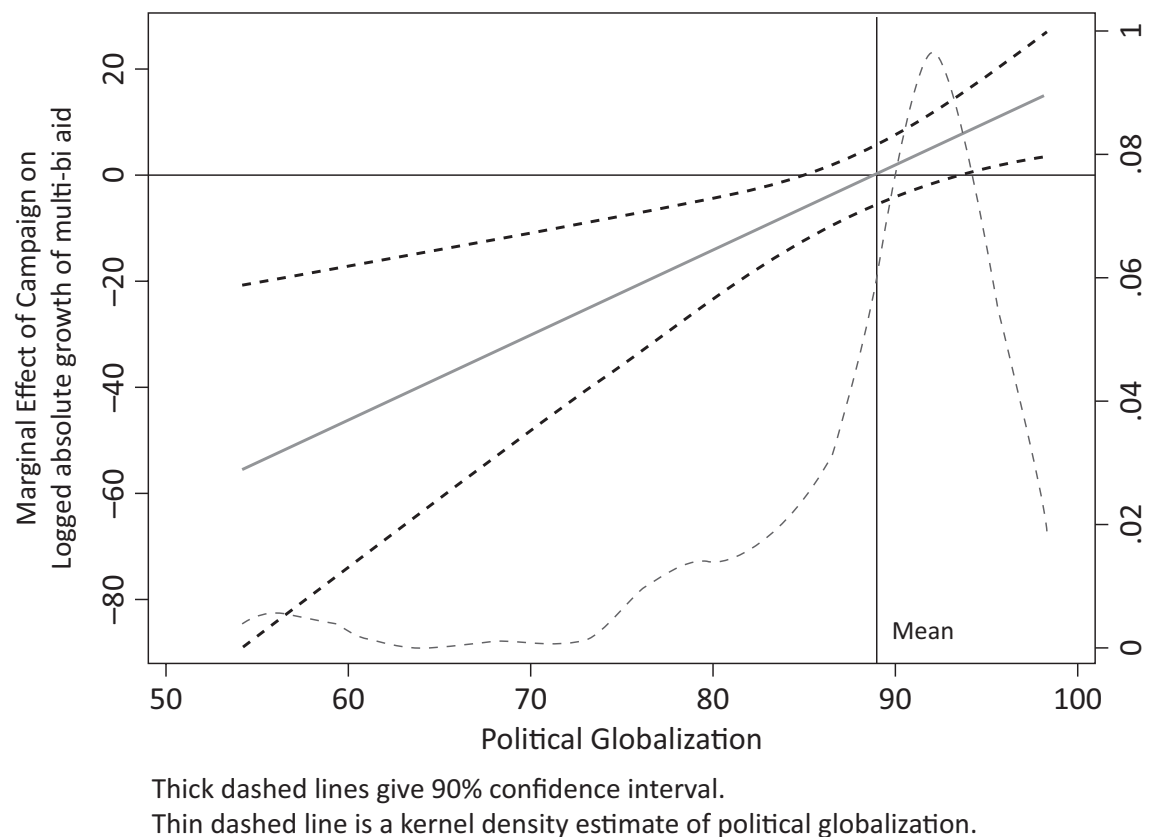

Figure 5. Marginal effect of campaigns on multi-bi aid growth conditional on political globalization.

Table 3 presents the results, indicating that most previous findings hold, some being more significant. Donor experience is a significantly positive predictor of bilateral aid growth in the context of UNSC campaigns. 25 years of additional experience now are related to bilateral aid growth of around USD 50 million $(p<0.05$ ). To the extent that a donor becomes more internationalized by a standard deviation, it accelerates its multilateral aid growth by USD 1,100 ( $p<0.1)$ and its multi-bi aid growth by about USD 140,000 ( $p<0.1$ ) during UNSC campaigns. Finally, campaigning significantly increases multibi aid growth if governance quality decreases $(p<0.05)$. As regards instrument strength, I find that peer campaigning is a positively significant predictor of individual campaigning, with the Kleibergen-Paap F-statistics being well above the conventional threshold $(F>10)$. The estimated sign implies that competition for a single UNSC seat drives donors toward intensifying their own campaigning.

\subsection{Robustness Checks}

In the appendix, I present the full results for the unconditional relationship between UNSC campaigning and aid growth for total aid (Table A1) and different aid channels (Table A2), before probing the robustness of my findings in several ways. First, I extend the set of controls to also include 'neighborhood variables,' which yields the additional finding that multi-bi aid growth is significantly positively related to the incidence of regional conflicts, but has otherwise no effect on the results (Table A3). My results also are qualitatively unchanged when dropping all control variables from the model, except for the country-fixed effects and year dummies (Table A4). Furthermore, I successfully replicate all findings using alternative measures of the moderator variables (Table A5). In another robustness test, I explore an alternative lag structure. When using the one-year lagged campaign measure, I find that less experienced donors significantly increase multi-bi aid growth to support their UNSC campaigns $(p<0.05)$. Conversely, political globalization loses its significant conditioning effect on campaign-induced multi-bi aid, but now significantly accelerates campaigninduced multilateral aid $(p<0.05)$. The interaction effect of UNSC campaigning and governance quality is robust (Table A6). In another robustness test, I add the three P5 donors to the sample. This does not affect the results (Table A7). Except for donor experience, all results are significant when using aid disbursements rather than aid commitments (Table A8). ${ }^{10}$ The relative consistency of the results implies that donors generally keep their promises to reward support for their UNSC bids with additional aid.

Yet another robustness test conducts all regressions without country-fixed effects. This alters the interpretation of the findings because estimated effects also refer to differences across donors, rather than inter-temporal differences within the same donors. For slow-moving variables, effects generally refer to cross-donor differences. Replicating the main analysis using pooled regressions, I find the main results to be remarkably robust (Table A9).

Finally, again using pooled regressions, I explore potential effect heterogeneity across three regional constituencies, notably EEG, WEOG, and APG (Table A10). I find that Asian donors increase bilateral aid to support

\footnotetext{
10 When lagging the campaign indicator, I obtain a significant conditional effect of donor experience on multi-bi aid growth, which may be due to delays in the actual disbursement of committed aid.
} 
Table 3. Instrumental variable analysis.

\begin{tabular}{|c|c|c|c|c|c|c|}
\hline \multirow[b]{2}{*}{ Bilateral aid growth } & \multicolumn{2}{|c|}{$\begin{array}{l}\text { Donor experience } \\
\text { (1) }\end{array}$} & \multicolumn{2}{|c|}{$\begin{array}{l}\text { Governance quality } \\
\text { (2) }\end{array}$} & \multicolumn{2}{|c|}{$\begin{array}{l}\text { Political globalization } \\
\text { (3) }\end{array}$} \\
\hline & & & & & & \\
\hline Campaign & $-18.170 * *$ & (7.799) & -19.289 & $(21.333)$ & 5.941 & $(42.521)$ \\
\hline Campaign $\times X$ & $5.513^{* *}$ & $(2.363)$ & 19.773 & $(23.675)$ & -0.104 & (0.498) \\
\hline $\mathrm{x}$ & 0.621 & $(1.945)$ & 12.919 & (19.828) & 0.162 & $(0.296)$ \\
\hline \multicolumn{7}{|l|}{ Multilateral aid growth } \\
\hline Campaign & -10.929 & (9.495) & 5.847 & $(24.303)$ & $-67.166^{*}$ & $(36.670)$ \\
\hline Campaign $\times X$ & 3.036 & $(2.982)$ & -7.839 & $(27.489)$ & $0.780^{*}$ & $(0.426)$ \\
\hline $\mathrm{x}$ & 2.753 & $(2.008)$ & -17.192 & $(22.106)$ & 0.103 & $(0.288)$ \\
\hline \multicolumn{7}{|l|}{ Multi-bi aid growth } \\
\hline Campaign & -4.192 & (9.386) & $44.190 *$ & $(23.090)$ & $-118.837^{* *}$ & $(57.898)$ \\
\hline Campaign $\times X$ & 1.008 & $(2.749)$ & $-50.911 * *$ & $(25.581)$ & $1.313^{*}$ & $(0.675)$ \\
\hline $\mathrm{x}$ & $-3.534^{*}$ & $(2.068)$ & -17.401 & $(24.245)$ & 0.070 & $(0.440)$ \\
\hline \multicolumn{7}{|l|}{ Campaign } \\
\hline Peer campaigning & $0.555^{* * *}$ & $(0.042)$ & $0.543^{* * *}$ & $(0.038)$ & $0.540 * * *$ & $(0.041)$ \\
\hline Country-fixed effects & yes & & yes & & yes & \\
\hline Year-fixed effects & yes & & yes & & yes & \\
\hline Control variables & yes & & yes & & yes & \\
\hline$N_{B} / R_{B}^{2}$ & 481 & 0.25 & 481 & 0.24 & 452 & 0.25 \\
\hline$N_{M} / R_{M}^{2}$ & 481 & 0.24 & 481 & 0.23 & 452 & 0.22 \\
\hline$N_{M B} / R_{M B}^{2}$ & 383 & 0.24 & 383 & 0.24 & 354 & 0.25 \\
\hline$\rho_{B, M}$ & 0.031 & $(0.046)$ & 0.032 & $(0.046)$ & 0.026 & $(0.048)$ \\
\hline$\rho_{B, M B}$ & 0.009 & $(0.053)$ & 0.008 & $(0.053)$ & -0.210 & $(0.054)$ \\
\hline$\rho_{M, M B}$ & 0.069 & $(0.054)$ & 0.067 & $(0.054)$ & 0.060 & $(0.056)$ \\
\hline F-statistic & 177.22 & & 201.62 & & 170.98 & \\
\hline
\end{tabular}

Notes: System of equations estimated simultaneously with dependent variables shown in row heads. Campaign is a binary indicator, $\mathrm{X}$ is the moderator in the respective column header, and Campaign $\times X$ the multiplicative interaction term. Baseline set of controls included in all equations. The instrument-peer campaigning-is defined as the number of other donors in the same constituency vying for the same seat. Abbreviations in the diagnostics section refer to the number of observations across bilateral aid $\left(N_{B}\right)$, multilateral aid $\left(N_{M}\right)$, and multi-bi aid $\left(N_{M B}\right)$, R-squared, and cross-equation correlations, respectively. Significance levels: $* p<.1 * * p<.05 * * * p<.01$.

a UNSC campaign ( $p<0.05)$, while WEOG donors tend to reduce it $(p<0.1)$. I find no significant conditional effects for EEG donors, which likely is the result of underpowered tests.

\section{Conclusion}

Do countries use foreign aid to support their campaigns for a temporary seat in the UN Security Council? I found some robust evidence of campaign-induced aid growth for some aid channels and under some circumstances. In particular, as donor experience increases, bilateral aid growth increases, whereas multi-bi aid growth tends to decline. Conversely, multi-bi aid growth increases with declining quality of governance and with the level of internationalization of a given donor.

A noteworthy limitation of this research is that some findings can still be interpreted in various ways. For example, while internationalization boosts multi-bi aid growth, it does not seem to affect bilateral aid growth. One interpretation is that there really is no effect on bilateral aid growth, but another one is that bilateral aid declines but the analysis fails to produce a statistically significant effect, for example due to measurement error. Despite best efforts, the data collection might be incomplete, which would generate measurement error. Other sources of insignificant effects include under-powered tests due to short time series as well as donor heterogeneity. These are common challenges of quantitative analysis that also this article cannot defy. Nonetheless, the above analysis produced results that are remarkably robust against several modifications, including instrumental-variable estimation.

Albeit necessarily preliminary, these findings suggest interesting avenues for future research. They demonstrate that donors care about UNSC membership. Existing studies emphasize the aid rewards for recipient countries during their temporary UNSC tenure. Future research could examine how aid flows evolve over the lifetime of a UNSC campaign, given that donors (including the ones that do not get elected) are likely to lessen aid effort once uncertainty is resolved after the outcome of a UNGA election. Studying how aid evolves during UNSC tenure would also hint to donor motiva- 
tions in this context and specifically which donors use aid for private gain versus fostering international solidarity. In this context, further research into donors of specific UN constituencies would be promising. For EEG donors, qualitative research would be necessary given the lack of long time-series data (Szent-Iványi, Reinsberg, \& Lightfoot, 2018). Capturing the donor perspective, future research could also examine the choice of instruments other than aid for supporting UNSC campaigns. Research could also explore which recipients stand to gain most from donor campaigns for UNSC seats. UItimately, researchers should examine the effectiveness of campaign-induced aid. Although previous research finds that aid extended to developing countries during their temporary UNSC tenure is less effective (Dreher, Eichenauer, \& Gehring, 2016), this does not need to be the case for campaign-induced aid for which donor motives are less clear.

\section{Acknowledgments}

I am grateful to Patrick Bayer, Michael Heaney, Marcin Kaczmarski, and participants of the Glasgow Quantitative Methods Colloquium for comments on an earlier draft.

\section{Conflict of Interests}

The author declares no conflict of interests.

\section{References}

Alesina, A., \& Dollar, D. (2000). Who gives foreign aid to whom and why? Journal of Economic Growth, 5(1), 33-63.

Australian Associated Press. (2008, September 23). Australia discusses UN bid with African nations. Australian Associated Press.

Bauhr, M., Charron, N., \& Nasiritousi, N. (2013). Does corruption cause aid fatigue? Public opinion and the aidcorruption paradox. International Studies Quarterly, 57(3), 568-579. https://doi.org/10.1111/isqu.12025

BBC Monitoring Africa. (2009, June 16). Australia to support Rwanda's commonwealth bid. BBC Monitoring Africa.

Beck, T., Clarke, G., Groff, A., Keefer, P., \& Walsh, P. (2001). New tools in comparative political economy: The database of political institutions. World Bank Economic Review, 15(1), 165-176.

Berthélemy, J.-C. (2006). Aid allocation: Comparing donors' behaviours. Swedish Economic Policy Review, 13(2), 75-109.

Bourguignon, F., \& Sundberg, M. (2007). Aid effectiveness: Opening the black box. The American Economic Review, 97(2005), 316-321. https://doi.org/ 10.1257/aer.97.2.316

Bueno de Mesquita, B., \& Smith, A. (2009). A political economy of aid. International Organization, 63(2), 309-340.
BusinessWorld. (2011, June 17). Military cooperation deals needed? BusinessWorld. Retrieved from http://www.bworldonline.com/content.php?section =TopStory\&title=mining-issues-to-be-addressed---gov\&8217t\&id $=33302$

CNN. (2008, October 16). Iceland, Iran eye U.N. Security Council. Retrieved from https://web.archive.org/ web/20081018204805/http://www.cnn.com/2008/ US/10/16/unsecurity.council.ap/index.html

Coppedge, M., Gerring, J., Lindberg, S. I., Skaaning, S.E., Teorell, J., Altman, D., . . Miri, F. (2016). V-Dem codebook v6. Varieties of democracy (VDem) project. Gothenburg: VDem-Institute.

CTK Daily News. (2006, February 14). Moroccan Prime Minister denounces Prophet Mohammad's cartoons. CTK Daily News.

Dietrich, S. (2013). Bypass or engage? Explaining donor delivery tactics in foreign aid allocation. International Studies Quarterly, 57(4), 698-712. https://doi.org/ 10.1111/isqu.12041

Dietrich, S., \& Wright, J. (2015). Foreign aid allocation tactics and democratic change in Africa. Journal of Politics, 77(1), 216-234.

Dominion Post. (2003, November 14). Spit and Polish cannot hide Sri Lanka's shame. Dominion Post.

Dreher, A. (2006). Does globalization affect growth? Evidence from a new index of globalization. Applied Economics, 38(10), 1091-1110.

Dreher, A., Eichenauer, V. Z., \& Gehring, K. (2016). Geopolitics, aid, and growth: The impact of UN Security Council membership on the effectiveness of aid. World Bank Economic Review, 32(2), 268-286.

Dreher, A., Gould, M., Rablen, M. D., \& Vreeland, J. R. (2014). The determinants of election to the United Nations Security Council. Public Choice, 158(1/2), 51-83. https://doi.org/10.1007/s11127-013-0096-4

Dreher, A., \& Kilby, C. (2010). The impact of aid on growth revisited: Do donor motives matter? Economic Letters, 107(3), 338-340.

Dreher, A., Klasen, S., Vreeland, J. R., \& Werker, E. (2013). The costs of favoritism: Is politically driven aid less effective? Economic Development and Cultural Change, 62(1), 157-191. https://doi.org/10.1086/671711

Dreher, A., Lang, V. F., Rosendorff, B. P., \& Vreeland, J. R. (2018). Buying votes and international organizations: The dirty work hypothesis (CESifo Working Paper no. 7329). Munich: CESifo.

Dreher, A., Langlotz, S., \& Marchesi, S. (2017). Information transmission and ownership consolidation in aid programs. Economic Inquiry, 55(4), 1671-1688. https://doi.org/10.1111/ecin.12450

Dreher, A., Sturm, J.-E., \& Vreeland, J. R. (2009). Development aid and international politics: Does membership on the UN Security Council influence World Bank decisions? Journal of Development Economics, 88(1), 1-18.

Eichenauer, V. Z., \& Reinsberg, B. (2017). What determines earmarked funding to international de- 
velopment organizations? Evidence from the new multi-bi aid data. Review of International Organizations, 12(2), 171-197. https://doi.org/10.1007/ s11558-017-9267-2

EM-DAT. (2018). The Emergency Events Database. Retrieved from www.emdat.be

Federal Department of Foreign Affairs. (2018). Switzerland registers its candidature for the UN Security Council for 2023-24. Federal Department of Foreign Affairs. Retrieved from https://www.admin.ch/gov/ en/start/dokumentation/medienmitteilungen.msgid-37154.html

Fuchs, A., \& Müller, A. (2018). Democracy and aid donorship (Kiel Working Paper No. 2113). Kiel: Kiel Institute for the World Economy.

Hawkins, D. G., Lake, D. A., Nielson, D. L., \& Tierney, M. J. (2006). Delegation under anarchy: states, international organizations, and principal-agent theory. In Delegation and agency in international organizations (pp. 3-38). Cambridge: Cambridge University Press.

Headey, D. (2008). Geopolitics and the effect of foreign aid on economic growth: 1970-2001. Journal of International Development, 20(2), 161-180.

Hoeffler, A., \& Outram, V. (2011). Need, merit, or selfinterest-what determines the allocation of aid? Review of Development Economics, 15(2), 237-250. https://doi.org/10.1111/j.1467-9361.2011.00605.x

Jacobsen, H. (2015, November 5). Sweden considers cutting development aid budget by $60 \%$ due to refugee crisis. Euractiv. Retrieved from https://www. euractiv.com/section/development-policy/news/ sweden-considers-cutting-development-aid-budgetby-60-due-to-refugee-crisis

Kilby, C. (2013). The political economy of project preparation: An empirical analysis of World Bank projects. Journal of Development Economics, 105, 211-225. https://doi.org/10.1016/j.jdeveco.2013.07.011

Kuziemko, I., \& Werker, E. (2006). How much is a seat on the Security Council worth? Foreign aid and bribery at the United Nations. Journal of Political Economy, 114(5), 905-930.

Laeven, L., \& Valencia, F. (2013). Systemic banking crises database. IMF Economic Review, 61(2), 225-270.

Lim, D. Y. M., \& Vreeland, J. R. (2013). Regional organizations and international politics: Japanese influence over the Asian Development Bank and the UN Security Council. Journal of Politics, 65(1), 34-72.

Lumsdaine, D. H. (1993). Moral vision in international politics: The foreign aid regime, 1949-1989. Princeton, NJ: Princeton University Press.

Mahoney, J., \& Goertz, G. (2004). The possibility principle: Choosing negative cases in comparative research. American Political Science Review, 98(4), 653-669.

Malone, D. M. (2000). Eyes on the prize: The quest for nonpermanent seats on the UN Security Council. Global Governance, 6(1), 3-23. https://doi.org/ $10.2307 / 27800251$
Mayer, T., \& Zignago, S. (2011). Notes on CEPII's distances measures: The GeoDist database (CEPII Working Paper, No. 2011-25). Paris: CEPII. Retrieved from https://ssrn.com/abstract=1994531

Mikulaschek, C. (2018). Issue linkage across international organizations: Does European countries' temporary membership in the UN Security Council increase their receipts from the EU budget? Review of International Organizations, 13(4), 491-518.

Milner, H. V. (2006). Why multilateralism? Foreign aid and domestic principal-agent problems. In D. G. Hawkins, D. A. Lake, D. L. Nielson, \& M. J. Tierney (Eds.), Delegation and agency in international organizations (pp. 107-139). Cambridge: Cambridge University Press. https://doi.org/10.1017/ CB09780511491368.005

Organization for Economic Cooperation and Development. (2018). Creditor reporting system: Aid activities. Organization for Economic Cooperation and Development. Retrieved from http://www.oecdilibrary.org/development/data/creditor-reportingsystem/aid-activities_data-00061-en

Prantl, J. (2005). Informal groups of states and the UN Security Council. International Organization, 59(3), 559-592. https://doi.org/10.1017/ S0020818305050204

Reinsberg, B. (2017). Trust funds as a lever of influence at international development organizations. Global Policy, 8(5), 85-95. https://doi.org/10.1111/1758-5899. 12464

Reinsberg, B., Michaelowa, K., \& Eichenauer, V. Z. (2015). The rise of multi-bi aid and the proliferation of trust funds. In M. Arvin \& B. L. Lew (Eds.), Handbook on the economics of foreign aid (pp. 527-554). Northhampton: Edward Elgar.

Reinsberg, B., Michaelowa, K., \& Knack, S. (2017). Which donors, which funds? Bilateral donors' choice of multilateral funds at the World Bank. International Organization, 71(4), 767-802. https://doi.org/10.1017/ S0020818317000340

Reuters. (2014, September 7). Abe becomes first Japanese PM to visit Sri Lanka in 24 years. Reuters. Retrieved from https://www.reuters.com/article/ussouthasia-japan-idUSKBNOH2OHW20140907

Roodman, D. (2012). Fitting fully observed recursive mixed-process models with cmp. Stata Journal, 11(2), 159-206. Retrieved from http://www.stata-journal. com/article.html?article $=$ st0224

Schmitz, J., \& Schwarze, J. (2012). Determinants of the election of non-permanent members to the United Nations Security Council: An empirical analysis. In 5th Annual Conference on the Political Economy of International Organizations. Retrieved from http://147.142.190.246/joomla/peio/files2012/ papers/Schmitz30.09.11.pdf

Security Council Report. (2009). Special research report. New York: Security Council Report.

Sridhar, D., \& Woods, N. (2013). Trojan multilateral- 
ism: Global cooperation in health. Global Policy, 4(4), 325-335.

Stone, R. W. (2009). Institutions, power and interdependence. New York: Cambridge University Press.

Szent-Iványi, B., Reinsberg, B., \& Lightfoot, S. (2018). Small states in world politics: The role of trust funds in the foreign aid policies of Central and Eastern European donors. European Journal of Development Research. https://doi.org/10.1057/s41287-018-0175-y

Teorell, J., Dahlberg, S., Holmberg, S., Rothstein, B., Alvarado, N. P., \& Svensson, R. (2018). The quality of government standard dataset, version Jan18. Retrieved from https://qog.pol.gu.se/data

The Age. (2010, July 21). Running up white flag on world stage. The Age.

The Canadian Press. (2014, March 3). Ottawa reduced to "gestures" on Ukraine response, say former top envoys. The Canadian Press.

The PRS Group. (2015). International Country Risk Guide (ICRG). Retrieved from https://www.prsgroup.com/ about-us/our-two-methodologies/icrg

United Nations. (1945). UN charter. New York, NY: United
Nations.

United Nations. (2016). General Assembly elects 4 new non-permanent members to Security Council, as Western and others group fails to fill final vacancy. United Nations. Retrieved from https://www.un.org/ press/en/2016/ga11796.doc.htm

Voeten, E. (2001). Outside options and the logic of Security Council action. American Political Science Review, 95(4), 845-858. https://doi.org/10.1017/ S000305540101005X

Vreeland, J. R., \& Dreher, A. (2014a). The political economy of the United Nations Security Council. Cambridge: Cambridge University Press.

Vreeland, J. R., \& Dreher, A. (2014b). Who wins election to represent the world? In J. R. Vreeland \& A. Dreher (Eds.), The political economy of the United Nations Security Council: Money and influence (pp. 94-136). Cambridge: Cambridge University Press.

Wright, J., \& Winters, M. S. (2010). The politics of effective foreign aid. Annual Review of Political Science, 13, 61-80.

\section{About the Author}

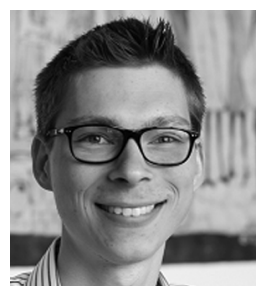

Bernhard Reinsberg is Lecturer in International Relations at the University of Glasgow. He also is affiliated to the Centre for Business Research at the University of Cambridge. He holds a PhD in Political Science from the University of Zurich, an MA in Comparative and International Studies at ETH Zurich and BA degrees in Political Science (Freie Universität Berlin) and Mathematics (University in Hagen). His research broadly covers the political economy of development and international organisations. 
Appendix A. Robustness tests.

Table A1. Unconditional effect of UNSC campaigning on total aid growth.

\begin{tabular}{|c|c|c|c|c|c|c|c|c|c|}
\hline & \multicolumn{3}{|c|}{ Media reports > 0} & \multicolumn{3}{|c|}{ In (1 + Media reports) } & \multicolumn{3}{|c|}{ Media reports $_{t-1}>0$} \\
\hline & $(1)$ & $(2)$ & (3) & (4) & $(5)$ & (6) & (7) & $(8)$ & (9) \\
\hline \multirow[t]{2}{*}{ (Column header) } & 0.159 & 0.337 & -0.110 & 1.420 & 1.641 & -0.971 & 1.517 & 1.666 & 1.396 \\
\hline & (3.656) & $(3.622)$ & $(2.929)$ & $(2.948)$ & $(2.812)$ & (2.359) & $(2.264)$ & $(2.284)$ & (2.839) \\
\hline \multirow[t]{2}{*}{ Financial crisis } & & 1.609 & 2.151 & & 1.709 & 2.091 & & 1.633 & 2.193 \\
\hline & & $(3.276)$ & $(3.261)$ & & (3.324) & (3.224) & & (3.309) & (3.308) \\
\hline \multirow[t]{2}{*}{ GDP growth } & & -0.047 & -0.021 & & -0.052 & -0.022 & & -0.048 & -0.019 \\
\hline & & $(0.157)$ & $(0.168)$ & & $(0.157)$ & $(0.169)$ & & $(0.158)$ & $(0.166)$ \\
\hline \multirow[t]{2}{*}{ Executive election } & & 0.033 & -0.009 & & 0.084 & -0.035 & & -0.053 & -0.082 \\
\hline & & $(2.780)$ & $(2.747)$ & & $(2.800)$ & $(2.734)$ & & $(2.765)$ & $(2.758)$ \\
\hline \multirow[t]{2}{*}{ Left-wing government } & & 2.261 & 2.084 & & 2.288 & 2.033 & & 2.276 & 2.149 \\
\hline & & $(1.550)$ & $(1.736)$ & & $(1.524)$ & (1.739) & & $(1.513)$ & $(1.680)$ \\
\hline \multirow[t]{2}{*}{ Government fractionalization } & & 0.861 & 1.757 & & 1.165 & 1.671 & & 1.119 & 1.908 \\
\hline & & $(3.916)$ & (3.978) & & (3.869) & (3.955) & & $(3.812)$ & (3.913) \\
\hline \multirow[t]{2}{*}{ Regional crises } & & & -1.500 & & & -1.713 & & & -1.070 \\
\hline & & & $(11.647)$ & & & $(11.755)$ & & & $(12.118)$ \\
\hline \multirow[t]{2}{*}{ Regional conflicts } & & & 2.572 & & & 2.606 & & & 2.633 \\
\hline & & & (3.996) & & & (3.929) & & & (3.908) \\
\hline \multirow[t]{2}{*}{ Regional disasters } & & & 0.304 & & & 0.263 & & & 0.355 \\
\hline & & & $(0.526)$ & & & (0.519) & & & $(0.630)$ \\
\hline \multirow[t]{2}{*}{ Lagged aid level } & $0.472 * * *$ & $0.472 * * *$ & $0.467 * * *$ & $0.474 * * *$ & $0.474 * * *$ & $0.465 * * *$ & $0.474 * * *$ & $0.474 * * *$ & $0.469 * * *$ \\
\hline & $(0.070)$ & $(0.071)$ & $(0.070)$ & (0.069) & $(0.071)$ & $(0.070)$ & (0.070) & $(0.071)$ & $(0.070)$ \\
\hline Country-fixed effects & yes & yes & yes & yes & yes & yes & yes & yes & yes \\
\hline Year-fixed effects & yes & yes & yes & yes & yes & yes & yes & yes & yes \\
\hline R-squared & 0.48 & 0.46 & 0.47 & 0.48 & 0.46 & 0.47 & 0.48 & 0.46 & 0.47 \\
\hline Observations & 814 & 753 & 709 & 814 & 753 & 709 & 814 & 753 & 709 \\
\hline
\end{tabular}

Notes: Campaign is either a binary indicator of media reports (column 1-3), the logged number of media reports (column 4-6), or the lagged binary indicator (column 7-9). Significance level: ${ }^{* * *} \mathrm{p}<.01$. 
Table A2. Unconditional effect of UNSC campaigning on aid growth for different aid channels.

\begin{tabular}{|c|c|c|c|c|c|c|}
\hline \multirow{2}{*}{ Bilateral aid growth } & \multicolumn{2}{|c|}{$\begin{array}{l}\text { Media reports }>0 \\
\text { (1) }\end{array}$} & \multicolumn{2}{|c|}{$\begin{array}{l}\text { In (1+ Media reports) } \\
(2)\end{array}$} & \multicolumn{2}{|c|}{$\begin{array}{l}\text { Media reports } t_{t-1}>0 \\
\text { (3) }\end{array}$} \\
\hline & & & & & & \\
\hline (Column header) & 2.289 & $(2.943)$ & 2.440 & $(2.363)$ & 0.441 & (2.978) \\
\hline Financial crisis & $-10.242^{* *}$ & $(4.611)$ & $-10.139 * *$ & $(4.591)$ & $-10.355^{* *}$ & $(4.707)$ \\
\hline GDP growth & 0.208 & $(0.440)$ & 0.194 & $(0.439)$ & 0.225 & $(0.449)$ \\
\hline Executive election & -4.459 & $(3.465)$ & -4.351 & $(3.467)$ & -4.259 & (3.469) \\
\hline Left-wing government & 0.782 & $(1.856)$ & 0.767 & $(1.851)$ & 0.714 & $(1.853)$ \\
\hline Government fractionalization & -4.331 & $(5.397)$ & -4.108 & $(5.387)$ & -4.482 & $(5.503)$ \\
\hline Lagged aid level & $-15.994 * * *$ & $(1.729)$ & $-16.002 * * *$ & $(1.730)$ & $-16.001 * * *$ & $(1.722)$ \\
\hline \multicolumn{7}{|l|}{ Multilateral aid growth } \\
\hline (Column header) & -1.256 & (3.060) & -0.844 & $(2.555)$ & -2.712 & (2.832) \\
\hline Financial crisis & 2.898 & $(5.337)$ & 2.863 & $(5.315)$ & 3.524 & $(5.414)$ \\
\hline GDP growth & $0.541^{*}$ & $(0.279)$ & $0.541^{*}$ & $(0.281)$ & $0.568 * *$ & $(0.280)$ \\
\hline Executive election & -4.290 & $(3.794)$ & -4.360 & $(3.787)$ & -4.566 & (3.767) \\
\hline Left-wing government & 2.164 & $(1.757)$ & 2.187 & $(1.756)$ & 2.106 & $(1.763)$ \\
\hline Government fractionalization & 1.826 & $(5.457)$ & 1.795 & $(5.489)$ & 1.302 & $(5.454)$ \\
\hline Lagged aid level & $-13.306 * * *$ & $(1.935)$ & $-13.317^{* * *}$ & (1.933) & $-13.450 * * *$ & (1.949) \\
\hline \multicolumn{7}{|l|}{ Multi-bi aid growth } \\
\hline (Column header) & 2.550 & (3.431) & 1.190 & (2.291) & 0.709 & (3.582) \\
\hline Financial crisis & -3.905 & $(3.380)$ & -3.672 & (3.373) & -3.815 & (3.381) \\
\hline GDP growth & 0.505 & $(0.405)$ & 0.502 & $(0.407)$ & 0.514 & $(0.405)$ \\
\hline Executive election & 6.111 & $(3.971)$ & 6.285 & (3.932) & 6.395 & (3.921) \\
\hline Left-wing government & 0.842 & $(1.928)$ & 0.736 & $(1.916)$ & 0.698 & (1.912) \\
\hline Government fractionalization & 3.755 & $(8.006)$ & 3.481 & $(8.025)$ & 3.126 & $(7.968)$ \\
\hline Lagged aid level & $-4.268 * * *$ & $(0.716)$ & $-4.286 * * *$ & $(0.714)$ & $-4.320 * * *$ & $(0.707)$ \\
\hline Country-fixed effects & yes & yes & yes & yes & yes & yes \\
\hline Year-fixed effects & yes & yes & yes & yes & yes & yes \\
\hline$N_{B} / R_{B}^{2}$ & 481 & 0.24 & 481 & 0.24 & 481 & 0.24 \\
\hline$N_{M} / R_{M}^{2}$ & 481 & 0.23 & 481 & 0.23 & 481 & 0.23 \\
\hline$N_{M B} / R_{M B}^{2}$ & 383 & 0.23 & 383 & 0.23 & 383 & 0.23 \\
\hline$\rho_{B, M}$ & 0.031 & $(0.046)$ & 0.031 & $(0.046)$ & 0.031 & $(0.046)$ \\
\hline$\rho_{B, M B}$ & 0.002 & $(0.053)$ & 0.001 & $(0.053)$ & 0.003 & $(0.053)$ \\
\hline$\rho_{M, M B}$ & 0.068 & $(0.054)$ & 0.067 & $(0.054)$ & 0.066 & $(0.054)$ \\
\hline
\end{tabular}

Notes: System of equations estimated simultaneously with dependent variables shown in row heads. Campaign is either a binary indicator of media reports (column 1), the logged number of media reports (column 2), or the lagged binary indicator (column 3 ). Significance levels: $* \mathrm{p}<.1 * * \mathrm{p}<.05 * * * \mathrm{p}<.01$. 
Table A3. UNSC campaign and aid growth with additional control variables.

\begin{tabular}{|c|c|c|c|c|c|c|}
\hline \multirow{2}{*}{ Bilateral aid growth } & \multicolumn{2}{|c|}{$\begin{array}{l}\text { Donor experience } \\
\text { (1) }\end{array}$} & \multicolumn{2}{|c|}{$\begin{array}{l}\text { Government quality } \\
\text { (2) }\end{array}$} & \multicolumn{2}{|c|}{$\begin{array}{l}\text { Political globalization } \\
\text { (3) }\end{array}$} \\
\hline & & & & & & \\
\hline Campaign & -8.158 & $(6.300)$ & -1.672 & $(18.175)$ & -3.468 & $(40.753)$ \\
\hline Campaign $\times \mathbf{X}$ & 3.858* & $(2.204)$ & 4.556 & $(21.407)$ & 0.056 & $(0.473)$ \\
\hline $\mathrm{x}$ & 0.318 & $(1.954)$ & 11.869 & $(19.847)$ & 0.103 & (0.294) \\
\hline Financial crisis & $-10.141 * *$ & $(4.580)$ & $-10.597^{* *}$ & $(4.548)$ & $-9.475^{* *}$ & (4.610) \\
\hline GDP growth & 0.205 & $(0.450)$ & 0.170 & $(0.455)$ & 0.565 & $(0.544)$ \\
\hline Executive election & -3.964 & $(3.590)$ & -4.553 & $(3.506)$ & -4.094 & (3.604) \\
\hline Left-wing government & 0.455 & $(1.890)$ & 0.593 & $(1.843)$ & 0.867 & $(1.882)$ \\
\hline Government fractionalization & -4.218 & $(5.362)$ & -4.426 & $(5.335)$ & -3.167 & $(5.688)$ \\
\hline Regional crises & -4.165 & $(12.090)$ & -5.048 & $(12.221)$ & -4.699 & $(12.557)$ \\
\hline Regional conflicts & 5.290 & $(7.432)$ & 5.437 & (7.438) & 8.009 & (7.549) \\
\hline Regional disasters & 0.475 & $(1.151)$ & 0.336 & $(1.162)$ & 0.733 & (1.201) \\
\hline Lagged aid level & $-15.798 * * *$ & $(1.731)$ & $-16.048 * * *$ & $(1.715)$ & $-17.694 * * *$ & (1.983) \\
\hline \multicolumn{7}{|l|}{ Multilateral aid growth } \\
\hline Campaign & -8.491 & (8.670) & 4.086 & $(23.136)$ & $-62.985^{*}$ & (36.791) \\
\hline Campaign $\times X$ & 2.474 & $(2.824)$ & -6.412 & $(26.381)$ & $0.718 *$ & $(0.427)$ \\
\hline $\mathrm{x}$ & 2.710 & (1.998) & -16.188 & $(22.004)$ & 0.128 & $(0.288)$ \\
\hline Financial crisis & 2.229 & $(5.367)$ & 2.540 & (5.279) & 2.778 & (5.391) \\
\hline GDP growth & $0.666 * *$ & $(0.283)$ & $0.646 * *$ & $(0.283)$ & $0.704 * *$ & $(0.326)$ \\
\hline Executive election & -3.675 & (3.789) & -4.003 & (3.731) & -4.059 & (3.651) \\
\hline Left-wing government & 1.515 & $(1.778)$ & 2.220 & (1.758) & 2.293 & (1.802) \\
\hline Government fractionalization & 0.817 & $(5.395)$ & 0.816 & $(5.514)$ & 0.999 & (5.923) \\
\hline Regional crises & 5.661 & $(8.975)$ & 5.415 & $(8.870)$ & 6.094 & $(8.880)$ \\
\hline Regional conflicts & 4.440 & $(7.416)$ & 4.203 & $(7.452)$ & 2.469 & (7.577) \\
\hline Regional disasters & $-1.862^{*}$ & (1.128) & $-1.890 *$ & (1.127) & -1.361 & (1.202) \\
\hline Lagged aid level & $-13.615^{* * *}$ & $(1.991)$ & $-13.347^{* * *}$ & $(1.927)$ & $-13.763 * * *$ & $(2.028)$ \\
\hline \multicolumn{7}{|l|}{ Multi-bi aid growth } \\
\hline Campaign & 2.363 & (9.065) & $50.414 * * *$ & $(18.254)$ & $-149.786 * * *$ & $(50.562)$ \\
\hline Campaign $\times \mathbf{X}$ & 0.205 & $(2.961)$ & $-54.216 * *$ & $(21.791)$ & $1.692 * * *$ & $(0.574)$ \\
\hline $\mathrm{x}$ & $-3.572 *$ & $(2.056)$ & -18.753 & $(24.020)$ & 0.014 & $(0.440)$ \\
\hline Financial crisis & -1.889 & $(3.604)$ & -1.755 & (3.670) & 0.367 & (3.934) \\
\hline GDP growth & 0.642 & $(0.407)$ & 0.622 & $(0.407)$ & 0.403 & $(0.493)$ \\
\hline Executive election & 6.152 & $(4.083)$ & 6.054 & (3.869) & 6.179 & (4.075) \\
\hline Left-wing government & 1.144 & $(1.962)$ & 0.509 & (1.916) & 1.001 & (1.971) \\
\hline Government fractionalization & 2.257 & (8.115) & 0.650 & (8.104) & 5.553 & (8.457) \\
\hline Regional crises & 16.746 & $(10.186)$ & 15.915 & $(10.254)$ & $17.055^{*}$ & (9.842) \\
\hline Regional conflicts & $13.487 * *$ & $(6.181)$ & $13.565^{* *}$ & $(6.083)$ & $12.347^{*}$ & (6.611) \\
\hline Regional disasters & -1.689 & $(1.165)$ & -1.609 & (1.133) & -0.692 & $(1.244)$ \\
\hline Lagged aid level & $-4.584 * * *$ & $(0.734)$ & $-4.348 * * *$ & $(0.704)$ & $-4.183 * * *$ & $(0.710)$ \\
\hline Country-fixed effects & yes & yes & yes & yes & yes & yes \\
\hline Year-fixed effects & yes & yes & yes & yes & yes & yes \\
\hline$N_{B} / R_{B}^{2}$ & 481 & 0.25 & 481 & 0.24 & 452 & 0.26 \\
\hline$N_{M} / R_{M}^{2}$ & 481 & 0.24 & 481 & 0.23 & 452 & 0.23 \\
\hline$N_{M B} / R_{M B}^{2}$ & 383 & 0.25 & 383 & 0.26 & 354 & 0.26 \\
\hline$\rho_{B, M}$ & 0.030 & $(0.046)$ & 0.034 & $(0.046)$ & 0.029 & $(0.048)$ \\
\hline$\rho_{B, M B}$ & 0.006 & $(0.053)$ & 0.007 & $(0.052)$ & -0.026 & (0.054) \\
\hline$\rho_{M, M B}$ & 0.052 & $(0.054)$ & 0.054 & $(0.054)$ & 0.052 & $(0.056)$ \\
\hline
\end{tabular}

Notes: System of equations estimated simultaneously with dependent variables shown in row heads. Campaign is binary, $\mathrm{X}$ is the moderator in the respective column header, and Campaign $\times X$ the multiplicative interaction term. For the two countries for which the neighborhood is empty (Australia and New Zealand), I set the respective values for the three regional variables to zero to avoid a drop in observations. Standard errors clustered on countries. Significance levels: $* p<.1 * * p<.05 * * * p<.01$. 
Table A4. UNSC campaign and aid growth without control variables.

\begin{tabular}{|c|c|c|c|c|c|c|}
\hline \multirow[b]{2}{*}{ Bilateral aid growth } & \multicolumn{2}{|c|}{$\begin{array}{l}\text { Donor experience } \\
\text { (1) }\end{array}$} & \multicolumn{2}{|c|}{$\begin{array}{l}\text { Government quality } \\
\text { (2) }\end{array}$} & \multicolumn{2}{|c|}{$\begin{array}{l}\text { Political globalization } \\
\text { (3) }\end{array}$} \\
\hline & & & & & & \\
\hline Campaign & -9.298 & $(5.872)$ & -4.470 & $(18.172)$ & 2.640 & (41.178) \\
\hline Campaign $\times X$ & $4.295^{* *}$ & $(2.114)$ & 7.917 & (21.438) & -0.010 & $(0.480)$ \\
\hline $\mathrm{x}$ & -0.081 & (1.881) & 7.376 & (20.116) & 0.126 & $(0.296)$ \\
\hline Lagged aid level & $-15.511^{* * *}$ & $(1.761)$ & $-15.746 * * *$ & (1.749) & $-17.438 * * *$ & $(2.026)$ \\
\hline \multicolumn{7}{|l|}{ Multilateral aid growth } \\
\hline Campaign & -9.315 & $(8.403)$ & 3.267 & $(23.585)$ & -54.172 & (37.156) \\
\hline Campaign $\times X$ & 2.830 & $(2.802)$ & -5.430 & (27.088) & 0.617 & $(0.433)$ \\
\hline $\mathrm{x}$ & 2.720 & (1.936) & -7.083 & (21.526) & 0.182 & $(0.276)$ \\
\hline Lagged aid level & $-13.894 * * *$ & (1.980) & $-13.637^{* * *}$ & $(1.880)$ & $-14.075^{* * *}$ & $(2.020)$ \\
\hline \multicolumn{7}{|l|}{ Multi-bi aid growth } \\
\hline Campaign & 2.044 & (9.254) & $56.936 * * *$ & (18.921) & $-146.578 * * *$ & (52.279) \\
\hline Campaign $\times X$ & 0.202 & (2.997) & $-61.710 * * *$ & $(22.260)$ & $1.647^{* * *}$ & $(0.593)$ \\
\hline $\mathrm{x}$ & $-3.387^{*}$ & $(2.036)$ & -9.094 & (24.533) & 0.055 & $(0.433)$ \\
\hline Lagged aid level & $-4.237 * * *$ & $(0.723)$ & $-3.998 * * *$ & $(0.690)$ & $-4.010 * * *$ & $(0.706)$ \\
\hline Country-fixed effects & yes & yes & yes & yes & yes & yes \\
\hline Year-fixed effects & yes & yes & yes & yes & yes & yes \\
\hline$N_{B} / R_{B}^{2}$ & 493 & 0.23 & 493 & 0.22 & 457 & 0.24 \\
\hline$N_{M} / R_{M}^{2}$ & 493 & 0.23 & 493 & 0.22 & 457 & 0.22 \\
\hline$N_{M B} / R_{M B}^{2}$ & 391 & 0.22 & 391 & 0.23 & 358 & 0.24 \\
\hline$\rho_{B, M}$ & 0.021 & $(0.046)$ & 0.025 & $(0.046)$ & 0.031 & $(0.048)$ \\
\hline$\rho_{B, M B}$ & -0.004 & $(0.052)$ & -0.002 & $(0.052)$ & -0.032 & $(0.053)$ \\
\hline$\rho_{M, M B}$ & 0.093* & $(0.054)$ & $0.094^{*}$ & $(0.054)$ & 0.072 & $(0.056)$ \\
\hline
\end{tabular}

Notes: System of equations estimated simultaneously with dependent variables shown in row heads. Campaign is binary, $\mathrm{X}$ is the moderator in the respective column header, and Campaign $\times X$ the multiplicative interaction term. Standard errors clustered on countries. Significance levels: $* p<.1 * * p<.05 * * * p<.01$. 
Table A5. Different operationalization of moderator variables.

\begin{tabular}{|c|c|c|c|c|c|c|}
\hline \multirow[b]{2}{*}{ Bilateral aid growth } & \multicolumn{2}{|c|}{$\begin{array}{l}\text { Donor experience } \\
\text { (1) }\end{array}$} & \multicolumn{2}{|c|}{$\begin{array}{l}\text { VDem corruption } \\
\text { (2) }\end{array}$} & \multicolumn{2}{|c|}{$\begin{array}{l}\text { Neighborhood size } \\
\text { (3) }\end{array}$} \\
\hline & & & & & & \\
\hline Campaign & -10.359 & (6.774) & 1.983 & (4.121) & 1.842 & (3.969) \\
\hline Campaign $\times X$ & 4.054* & $(2.174)$ & 7.979 & $(24.426)$ & 0.043 & $(0.244)$ \\
\hline $\mathrm{x}$ & -0.078 & $(1.180)$ & $-80.863 *$ & (42.169) & $-1.296 * * *$ & $(0.248)$ \\
\hline Financial crisis & $-9.685^{* *}$ & $(4.675)$ & -7.685 & $(4.786)$ & $-10.252 * *$ & (4.609) \\
\hline GDP growth & 0.194 & $(0.444)$ & 0.148 & $(0.456)$ & 0.212 & $(0.442)$ \\
\hline Executive election & -3.495 & $(3.621)$ & -4.712 & $(3.388)$ & -4.567 & (3.543) \\
\hline Left-wing government & 0.474 & $(1.882)$ & 0.576 & $(1.842)$ & 0.834 & $(1.852)$ \\
\hline Government fractionalization & -4.073 & (5.339) & -3.920 & $(5.237)$ & -4.393 & $(5.432)$ \\
\hline Lagged aid level & $-15.581^{* * *}$ & $(1.804)$ & $-15.794 * * *$ & $(1.773)$ & $-16.018^{* * *}$ & (1.748) \\
\hline \multicolumn{7}{|l|}{ Multilateral aid growth } \\
\hline Campaign & -6.274 & (8.893) & 0.863 & (3.951) & -0.723 & $(4.065)$ \\
\hline Campaign $\times X$ & 1.435 & $(2.723)$ & -18.235 & $(30.258)$ & -0.050 & $(0.292)$ \\
\hline $\mathrm{x}$ & 0.669 & (1.111) & -37.057 & (43.678) & $-0.480 * * *$ & $(0.163)$ \\
\hline Financial crisis & 2.505 & $(5.382)$ & 3.104 & $(5.542)$ & 2.911 & $(5.346)$ \\
\hline GDP growth & $0.567^{* *}$ & $(0.282)$ & $0.676 * *$ & $(0.286)$ & $0.536^{*}$ & $(0.281)$ \\
\hline Executive election & -3.890 & (3.891) & -4.252 & (3.792) & -4.165 & (3.849) \\
\hline Left-wing government & 1.917 & $(1.771)$ & 1.892 & $(1.762)$ & 2.104 & $(1.773)$ \\
\hline Government fractionalization & 2.003 & $(5.404)$ & 1.580 & (5.482) & 1.901 & $(5.467)$ \\
\hline Lagged aid level & $-13.134^{* * *}$ & $(1.944)$ & $-13.291 * * *$ & $(2.008)$ & $-13.271 * * *$ & (1.932) \\
\hline \multicolumn{7}{|l|}{ Multi-bi aid growth } \\
\hline Campaign & -1.951 & (9.689) & -1.863 & $(4.236)$ & -1.554 & (4.327) \\
\hline Campaign $\times X$ & 1.388 & (3.012) & $75.563 * *$ & $(29.841)$ & $0.476 *$ & $(0.274)$ \\
\hline $\mathrm{x}$ & -1.544 & (1.195) & -35.449 & (54.308) & -0.123 & $(0.171)$ \\
\hline Financial crisis & -3.656 & $(3.294)$ & -3.405 & (3.579) & -3.834 & $(3.448)$ \\
\hline GDP growth & 0.500 & $(0.402)$ & 0.441 & $(0.411)$ & 0.557 & $(0.407)$ \\
\hline Executive election & 6.262 & $(4.102)$ & 5.638 & (3.969) & 5.479 & $(4.083)$ \\
\hline Left-wing government & 1.035 & $(1.930)$ & 0.432 & $(1.942)$ & 1.125 & (1.939) \\
\hline Government fractionalization & 3.530 & $(7.982)$ & 2.445 & $(8.194)$ & 2.999 & (8.009) \\
\hline Lagged aid level & $-4.410 * * *$ & $(0.746)$ & $-4.250 * * *$ & $(0.737)$ & $-4.255^{* * *}$ & $(0.710)$ \\
\hline Country-fixed effects & yes & yes & yes & yes & yes & yes \\
\hline Year-fixed effects & yes & yes & yes & yes & yes & yes \\
\hline$N_{B} / R_{B}^{2}$ & 475 & 0.24 & 459 & 0.25 & 481 & 0.24 \\
\hline$N_{M} / R_{M}^{2}$ & 475 & 0.23 & 459 & 0.24 & 481 & 0.23 \\
\hline$N_{M B} / R_{M B}^{2}$ & 383 & 0.24 & 372 & 0.24 & 383 & 0.24 \\
\hline$\rho_{B, M}$ & 0.022 & $(0.046)$ & 0.021 & $(0.047)$ & 0.031 & $(0.046)$ \\
\hline$\rho_{B, M B}$ & 0.001 & $(0.053)$ & -0.001 & $(0.054)$ & 0.004 & $(0.053)$ \\
\hline$\rho_{M, M B}$ & 0.067 & $(0.054)$ & 0.065 & $(0.055)$ & 0.070 & $(0.054)$ \\
\hline
\end{tabular}

Notes: System of equations estimated simultaneously with dependent variables shown in row heads. Campaign is binary, $\mathrm{X}$ is the moderator in the respective column header, and Campaign $\times X$ the multiplicative interaction term. Donor experience was taken from Fuchs and Müller (2018). Standard errors clustered on countries. Significance levels: $* p<.1 * * p<.05 * * * p<.01$. 
Table A6. Lagged effect of donor campaigning.

\begin{tabular}{|c|c|c|c|c|c|c|}
\hline \multirow[b]{2}{*}{ Bilateral aid growth } & \multicolumn{2}{|c|}{$\begin{array}{l}\text { Donor experience } \\
\text { (1) }\end{array}$} & \multicolumn{2}{|c|}{$\begin{array}{l}\text { Government quality } \\
\text { (2) }\end{array}$} & \multicolumn{2}{|c|}{$\begin{array}{l}\text { Political globalization } \\
\text { (3) }\end{array}$} \\
\hline & & & & & & \\
\hline Campaign & $8.141 *$ & $(4.837)$ & 8.314 & $(17.311)$ & 44.588 & $(38.068)$ \\
\hline Campaign $\times X$ & -2.873 & $(1.933)$ & -9.352 & $(20.491)$ & -0.532 & $(0.450)$ \\
\hline $\mathrm{x}$ & 0.074 & (1.944) & 13.410 & (19.779) & 0.189 & $(0.300)$ \\
\hline Financial crisis & $-10.291^{* *}$ & $(4.766)$ & $-10.440 * *$ & $(4.756)$ & $-9.628^{* *}$ & $(4.815)$ \\
\hline GDP growth & 0.225 & $(0.452)$ & 0.196 & $(0.451)$ & 0.602 & $(0.542)$ \\
\hline Executive election & -4.258 & (3.513) & -4.343 & $(3.481)$ & -4.021 & (3.630) \\
\hline Left-wing government & 0.901 & $(1.909)$ & 0.714 & $(1.855)$ & 0.890 & (1.875) \\
\hline Government fractionalization & -4.849 & $(5.532)$ & -4.456 & $(5.461)$ & -3.671 & (5.758) \\
\hline Lagged aid level & $-15.756 * * *$ & $(1.734)$ & $-15.984 * * *$ & $(1.710)$ & $-17.575^{* * *}$ & (1.963) \\
\hline \multicolumn{7}{|l|}{ Multilateral aid growth } \\
\hline Campaign & -6.046 & (6.928) & -14.365 & (17.798) & $-80.959 * *$ & $(32.406)$ \\
\hline Campaign $\times X$ & 1.150 & (2.399) & 13.858 & $(20.695)$ & $0.912^{* *}$ & $(0.382)$ \\
\hline $\mathrm{x}$ & 2.630 & $(1.987)$ & -18.184 & $(22.000)$ & 0.027 & (0.293) \\
\hline Financial crisis & 3.296 & $(5.390)$ & 3.640 & $(5.353)$ & 4.189 & $(5.347)$ \\
\hline GDP growth & $0.604^{* *}$ & $(0.280)$ & $0.608^{* *}$ & $(0.282)$ & $0.611^{*}$ & $(0.326)$ \\
\hline Executive election & -4.614 & $(3.698)$ & -4.466 & (3.703) & -4.190 & (3.594) \\
\hline Left-wing government & 1.514 & $(1.808)$ & 2.101 & $(1.775)$ & 2.094 & (1.796) \\
\hline Government fractionalization & 1.318 & $(5.407)$ & 1.328 & $(5.460)$ & 1.049 & (5.835) \\
\hline Lagged aid level & $-13.693^{* * *}$ & $(2.015)$ & $-13.321 * * *$ & $(1.964)$ & $-13.818^{* * *}$ & $(2.053)$ \\
\hline \multicolumn{7}{|l|}{ Multi-bi aid growth } \\
\hline Campaign & $20.603 * * *$ & (7.748) & $32.545^{*}$ & $(18.125)$ & 33.656 & $(64.446)$ \\
\hline Campaign $\times X$ & $-6.483 * *$ & $(2.724)$ & $-36.594 *$ & $(21.123)$ & -0.352 & $(0.731)$ \\
\hline $\mathrm{x}$ & $-4.084 * *$ & $(2.063)$ & -25.281 & $(23.736)$ & 0.075 & $(0.443)$ \\
\hline Financial crisis & -2.280 & $(3.375)$ & -3.516 & (3.357) & -2.667 & (3.666) \\
\hline GDP growth & 0.523 & $(0.403)$ & 0.488 & $(0.401)$ & 0.204 & $(0.452)$ \\
\hline Executive election & $6.663^{*}$ & (3.990) & $6.563^{*}$ & $(3.875)$ & $6.613^{*}$ & $(4.020)$ \\
\hline Left-wing government & 1.341 & $(1.932)$ & 0.525 & $(1.906)$ & 1.510 & (1.967) \\
\hline Government fractionalization & 3.356 & (7.971) & 2.371 & (8.019) & 8.812 & (8.225) \\
\hline Lagged aid level & $-4.594 * * *$ & $(0.717)$ & $-4.373 * * *$ & $(0.712)$ & $-4.141 * * *$ & $(0.723)$ \\
\hline Country-fixed effects & yes & yes & yes & yes & yes & yes \\
\hline Year-fixed effects & yes & yes & yes & yes & yes & yes \\
\hline$N_{B} / R_{B}^{2}$ & 481 & 0.24 & 481 & 0.24 & 452 & 0.26 \\
\hline$N_{M} / R_{M}^{2}$ & 481 & 0.23 & 481 & 0.23 & 452 & 0.23 \\
\hline$N_{M B} / R_{M B}^{2}$ & 383 & 0.24 & 383 & 0.24 & 354 & 0.24 \\
\hline$\rho_{B, M}$ & 0.033 & $(0.046)$ & 0.032 & $(0.046)$ & 0.032 & $(0.048)$ \\
\hline$\rho_{B, M B}$ & -0.004 & $(0.053)$ & 0.000 & $(0.053)$ & -0.020 & $(0.054)$ \\
\hline$\rho_{M, M B}$ & 0.065 & $(0.054)$ & 0.067 & $(0.054)$ & 0.063 & $(0.056)$ \\
\hline
\end{tabular}

Notes: System of equations estimated simultaneously with dependent variables shown in row heads. Campaign is binary and lagged by one year, $\mathrm{X}$ is the moderator in the respective column header, and Campaign $\times \mathrm{X}$ the multiplicative interaction term. Standard errors clustered on countries. Significance levels: ${ }^{*} p<.1 * * p<.05^{* * *} p<.01$. 
Table A7. Including P5 observations in the sample.

\begin{tabular}{|c|c|c|c|c|c|c|}
\hline \multirow[b]{2}{*}{ Bilateral aid growth } & \multicolumn{2}{|c|}{$\begin{array}{l}\text { Donor experience } \\
\text { (1) }\end{array}$} & \multicolumn{2}{|c|}{$\begin{array}{l}\text { Government quality } \\
\text { (2) }\end{array}$} & \multicolumn{2}{|c|}{$\begin{array}{l}\text { Political globalization } \\
\text { (3) }\end{array}$} \\
\hline & & & & & & \\
\hline Campaign & -9.230 & $(6.130)$ & -7.278 & $(18.357)$ & 4.525 & (41.778) \\
\hline Campaign $\times X$ & 4.226* & $(2.161)$ & 11.220 & (21.671) & -0.037 & $(0.486)$ \\
\hline $\mathrm{x}$ & 0.989 & $(1.785)$ & 4.539 & (18.684) & 0.131 & $(0.287)$ \\
\hline Financial crisis & $-11.882 * * *$ & $(3.852)$ & $-11.987 * * *$ & $(3.836)$ & $-11.273 * * *$ & (3.842) \\
\hline GDP growth & 0.184 & $(0.420)$ & 0.160 & $(0.426)$ & 0.490 & $(0.512)$ \\
\hline Executive election & -0.747 & $(3.202)$ & -1.066 & (3.187) & -0.743 & (3.213) \\
\hline Left-wing government & -0.027 & $(1.782)$ & 0.223 & $(1.744)$ & 0.482 & $(1.778)$ \\
\hline Government fractionalization & -4.945 & $(5.298)$ & -5.256 & $(5.283)$ & -4.196 & (5.584) \\
\hline Lagged aid level & $-16.589 * * *$ & $(1.729)$ & $-16.858^{* * *}$ & $(1.714)$ & $-18.469 * * *$ & (1.978) \\
\hline \multicolumn{7}{|l|}{ Multilateral aid growth } \\
\hline Campaign & -8.969 & $(8.395)$ & 5.141 & $(23.961)$ & $-69.063 *$ & $(35.260)$ \\
\hline Campaign $\times X$ & 2.771 & $(2.792)$ & -7.076 & $(27.469)$ & $0.788 *$ & $(0.413)$ \\
\hline $\mathrm{x}$ & $3.257^{*}$ & $(1.803)$ & -33.712 & $(20.623)$ & 0.074 & $(0.274)$ \\
\hline Financial crisis & 3.992 & (4.613) & 4.743 & (4.512) & 4.346 & (4.634) \\
\hline GDP growth & $0.701 * *$ & $(0.273)$ & $0.716 * * *$ & $(0.274)$ & $0.772 * *$ & $(0.316)$ \\
\hline Executive election & 2.165 & $(3.434)$ & 2.149 & (3.369) & 2.003 & (3.399) \\
\hline Left-wing government & 2.442 & $(1.660)$ & $3.235^{*}$ & $(1.652)$ & $3.390 * *$ & $(1.677)$ \\
\hline Government fractionalization & 4.179 & $(5.187)$ & 3.701 & (5.284) & 3.568 & (5.599) \\
\hline Lagged aid level & $-14.743^{* * *}$ & $(2.038)$ & $-14.319 * * *$ & $(1.964)$ & $-14.875^{* * *}$ & $(2.042)$ \\
\hline \multicolumn{7}{|l|}{ Multi-bi aid growth } \\
\hline Campaign & 1.285 & (9.439) & $51.470 * * *$ & $(18.294)$ & $-149.111 * * *$ & $(52.252)$ \\
\hline Campaign $\times X$ & 0.516 & (3.045) & $-55.608 * *$ & $(21.693)$ & $1.681 * * *$ & $(0.593)$ \\
\hline $\mathrm{x}$ & -2.190 & (1.976) & -29.547 & $(23.160)$ & -0.157 & $(0.468)$ \\
\hline Financial crisis & -0.432 & $(4.067)$ & -0.090 & (4.018) & 1.232 & (4.192) \\
\hline GDP growth & 0.521 & $(0.403)$ & 0.516 & $(0.404)$ & 0.281 & $(0.461)$ \\
\hline Executive election & 2.575 & $(3.572)$ & 2.499 & (3.496) & 2.988 & (3.599) \\
\hline Left-wing government & 1.281 & $(1.820)$ & 0.843 & $(1.772)$ & 1.180 & $(1.820)$ \\
\hline Government fractionalization & 2.645 & $(7.641)$ & 0.860 & (7.665) & 5.858 & (7.935) \\
\hline Lagged aid level & $-3.967 * * *$ & $(0.655)$ & $-3.902 * * *$ & $(0.651)$ & $-3.796 * * *$ & $(0.659)$ \\
\hline Country-fixed effects & yes & yes & yes & yes & yes & yes \\
\hline Year-fixed effects & yes & yes & yes & yes & yes & yes \\
\hline$N_{B} / R_{B}^{2}$ & 547 & 0.24 & 547 & 0.23 & 515 & 0.25 \\
\hline$N_{M} / R_{M}^{2}$ & 547 & 0.23 & 547 & 0.22 & 515 & 0.22 \\
\hline$N_{M B} / R_{M B}^{2}$ & 437 & 0.21 & 437 & 0.22 & 405 & 0.22 \\
\hline$\rho_{B, M}$ & 0.064 & $(0.043)$ & 0.069 & $(0.043)$ & 0.056 & $(0.045)$ \\
\hline$\rho_{B, M B}$ & 0.006 & $(0.049)$ & 0.008 & $(0.049)$ & -0.009 & $(0.05)$ \\
\hline$\rho_{M, M B}$ & $0.087^{*}$ & $(0.051)$ & $0.085^{*}$ & $(0.051)$ & $0.086^{*}$ & $(0.052)$ \\
\hline
\end{tabular}

Notes: System of equations estimated simultaneously with dependent variables shown in row heads. Campaign is binary, $\mathrm{X}$ is the moderator in the respective column header, and Campaign $\times X$ the multiplicative interaction term. Standard errors clustered on countries. Significance levels: ${ }^{*} p<.1 * * p<.05^{* * *} p<.01$. 
Table A8. Using aid disbursements rather than aid commitments.

\begin{tabular}{|c|c|c|c|c|c|c|}
\hline \multirow[b]{2}{*}{ Bilateral aid growth } & \multicolumn{2}{|c|}{$\begin{array}{l}\text { Donor experience } \\
\text { (1) }\end{array}$} & \multicolumn{2}{|c|}{$\begin{array}{l}\text { Government quality } \\
\text { (2) }\end{array}$} & \multicolumn{2}{|c|}{$\begin{array}{l}\text { Political globalization } \\
\text { (3) }\end{array}$} \\
\hline & & & & & & \\
\hline Campaign & -2.848 & $(4.785)$ & -1.698 & $(13.497)$ & -9.278 & $(19.105)$ \\
\hline Campaign $\times \mathbf{X}$ & 1.578 & $(1.807)$ & 3.090 & $(16.516)$ & 0.122 & $(0.231)$ \\
\hline $\mathrm{x}$ & 1.400 & (1.747) & -10.354 & $(18.503)$ & 0.150 & $(0.192)$ \\
\hline Financial crisis & -2.489 & (4.191) & -2.450 & $(4.092)$ & -1.731 & (4.073) \\
\hline GDP growth & $0.608^{*}$ & $(0.369)$ & 0.535 & $(0.337)$ & $0.759 * *$ & $(0.351)$ \\
\hline Executive election & -1.633 & $(2.639)$ & -2.273 & $(2.548)$ & -1.997 & $(2.583)$ \\
\hline Left-wing government & -0.955 & $(1.728)$ & -0.635 & $(1.683)$ & -0.727 & (1.725) \\
\hline Government fractionalization & $-13.103 * *$ & $(5.136)$ & $-13.983 * * *$ & $(5.327)$ & $-11.858^{* *}$ & (5.419) \\
\hline Lagged aid level & $-5.369 * * *$ & $(1.207)$ & $-5.521^{* * *}$ & $(1.190)$ & $-6.122 * * *$ & $(1.259)$ \\
\hline \multicolumn{7}{|l|}{ Multilateral aid growth } \\
\hline Campaign & -2.280 & (4.546) & -4.778 & $(11.923)$ & $-30.520 *$ & (18.319) \\
\hline Campaign $\times \mathbf{X}$ & 1.312 & (1.739) & 7.399 & $(14.590)$ & $0.377^{*}$ & $(0.221)$ \\
\hline $\mathrm{x}$ & 0.649 & $(1.628)$ & $-30.903^{*}$ & (18.088) & 0.127 & $(0.185)$ \\
\hline Financial crisis & $8.983 * *$ & $(3.690)$ & $7.860 * *$ & (3.603) & $8.598 * *$ & (3.566) \\
\hline GDP growth & $0.493 * *$ & $(0.216)$ & 0.289 & $(0.204)$ & 0.323 & $(0.228)$ \\
\hline Executive election & $-5.748 * *$ & $(2.683)$ & $-4.974 *$ & $(2.634)$ & $-4.763^{*}$ & $(2.664)$ \\
\hline Left-wing government & -0.062 & $(1.558)$ & 0.061 & $(1.534)$ & 0.050 & $(1.581)$ \\
\hline Government fractionalization & 2.593 & (4.269) & 1.962 & $(4.282)$ & 3.176 & (4.573) \\
\hline Lagged aid level & $-6.786 * * *$ & $(1.170)$ & $-7.427^{* * *}$ & $(1.204)$ & $-7.065^{* * *}$ & $(1.231)$ \\
\hline \multicolumn{7}{|l|}{ Multi-bi aid growth } \\
\hline Campaign & $12.164 *$ & (7.165) & $53.331 * * *$ & (19.296) & $-140.347 * *$ & (61.275) \\
\hline Campaign $\times \mathbf{X}$ & -2.869 & $(2.524)$ & $-57.431 * *$ & $(22.965)$ & $1.589 * *$ & $(0.693)$ \\
\hline $\mathrm{x}$ & $-5.632 * * *$ & $(2.101)$ & -17.606 & $(24.559)$ & 0.376 & $(0.412)$ \\
\hline Financial crisis & 0.635 & $(5.500)$ & 0.501 & $(5.492)$ & 0.621 & $(5.376)$ \\
\hline GDP growth & 0.529 & $(0.392)$ & 0.520 & $(0.395)$ & 0.301 & $(0.465)$ \\
\hline Executive election & 3.563 & $(4.113)$ & 3.680 & $(4.087)$ & 4.777 & (4.145) \\
\hline Left-wing government & 3.051 & $(1.951)$ & 2.019 & $(1.924)$ & 1.955 & (1.979) \\
\hline Government fractionalization & 9.848 & $(8.001)$ & 8.048 & (8.093) & 10.839 & (8.386) \\
\hline Lagged aid level & $-4.775^{* * *}$ & (0.759) & $-4.397 * * *$ & $(0.736)$ & $-4.299 * * *$ & $(0.748)$ \\
\hline Country-fixed effects & yes & yes & yes & yes & yes & yes \\
\hline Year-fixed effects & yes & yes & yes & yes & yes & yes \\
\hline$N_{B} / R_{B}^{2}$ & 590 & 0.18 & 628 & 0.18 & 594 & 0.19 \\
\hline$N_{M} / R_{M}^{2}$ & 590 & 0.19 & 628 & 0.19 & 594 & 0.18 \\
\hline$N_{M B} / R_{M B}^{2}$ & 386 & 0.23 & 388 & 0.23 & 358 & 0.23 \\
\hline$\rho_{B, M}$ & $0.078^{*}$ & $(0.043)$ & 0.070 & $(0.042)$ & 0.065 & $(0.043)$ \\
\hline$\rho_{B, M B}$ & -0.060 & $(0.051)$ & -0.065 & $(0.050)$ & $-0.086^{*}$ & $(0.051)$ \\
\hline$\rho_{M, M B}$ & -0.004 & $(0.051)$ & -0.007 & $(0.051)$ & -0.016 & $(0.052)$ \\
\hline
\end{tabular}

Notes: System of equations estimated simultaneously with dependent variables shown in row heads. Campaign is binary, $\mathrm{X}$ is the moderator in the respective column header, and Campaign $\times X$ the multiplicative interaction term. Standard errors clustered on countries. Significance levels: ${ }^{*} p<.1 * * p<.05^{* * *} p<.01$. 
Table A9. Pooled SUR estimations.

\begin{tabular}{|c|c|c|c|c|c|c|}
\hline \multirow{2}{*}{ Bilateral aid growth } & \multicolumn{2}{|c|}{$\begin{array}{l}\text { Donor experience } \\
\text { (1) }\end{array}$} & \multicolumn{2}{|c|}{$\begin{array}{l}\text { Government quality } \\
(2)\end{array}$} & \multicolumn{2}{|c|}{$\begin{array}{l}\text { Political globalization } \\
\text { (3) }\end{array}$} \\
\hline & & & & & & \\
\hline Campaign & -10.000 & (6.101) & 7.008 & $(19.466)$ & 6.516 & $(34.872)$ \\
\hline Campaign $\times X$ & 4.112* & $(2.160)$ & -7.143 & $(22.805)$ & -0.072 & $(0.408)$ \\
\hline $\mathrm{x}$ & 0.647 & $(0.728)$ & 13.583 & $(8.960)$ & 0.145 & $(0.114)$ \\
\hline Financial crisis & $-8.866^{*}$ & $(4.814)$ & $-8.546^{*}$ & $(4.856)$ & $-8.739 *$ & (4.931) \\
\hline GDP growth & 0.272 & $(0.424)$ & 0.219 & $(0.419)$ & 0.693 & $(0.512)$ \\
\hline Executive election & -4.459 & (3.808) & -5.597 & (3.789) & -4.958 & (3.682) \\
\hline Left-wing government & 0.539 & $(1.751)$ & 0.546 & $(1.771)$ & 1.019 & $(1.842)$ \\
\hline Government fractionalization & 1.847 & $(3.084)$ & 0.101 & (3.384) & 3.861 & (3.177) \\
\hline Lagged aid level & $-3.167 * * *$ & $(0.679)$ & $-3.181 * * *$ & $(0.693)$ & $-3.306 * * *$ & $(0.866)$ \\
\hline EEG & $-11.755^{* *}$ & $(4.850)$ & $-12.245^{* * *}$ & (4.749) & $-17.752 * * *$ & (5.684) \\
\hline WEOG & $-7.711^{* *}$ & $(3.002)$ & $-9.454 * * *$ & $(3.164)$ & $-9.674 * * *$ & (3.447) \\
\hline \multicolumn{7}{|l|}{ Multilateral aid growth } \\
\hline Campaign & -7.104 & (7.707) & 13.674 & $(21.645)$ & -53.925 & $(36.596)$ \\
\hline Campaign $\times \mathbf{X}$ & 2.829 & $(2.646)$ & -15.005 & (24.669) & 0.641 & $(0.427)$ \\
\hline $\mathrm{x}$ & -0.056 & $(0.695)$ & -1.928 & (8.589) & $0.267 * *$ & $(0.121)$ \\
\hline Financial crisis & 3.423 & $(5.781)$ & 2.940 & $(5.750)$ & 3.132 & (5.910) \\
\hline GDP growth & $0.499 * *$ & $(0.249)$ & $0.493 * *$ & $(0.250)$ & $0.576^{*}$ & (0.303) \\
\hline Executive election & -5.982 & (3.913) & $-6.683^{*}$ & $(3.767)$ & $-7.338 * *$ & (3.637) \\
\hline Left-wing government & 1.798 & $(1.684)$ & 2.072 & $(1.691)$ & 1.721 & $(1.760)$ \\
\hline Government fractionalization & 3.700 & (3.132) & 4.056 & $(3.447)$ & 4.190 & (3.215) \\
\hline Lagged aid level & $-1.975^{* * *}$ & $(0.629)$ & $-1.963 * * *$ & $(0.616)$ & $-3.321 * * *$ & $(0.878)$ \\
\hline EEG & 2.123 & $(4.430)$ & 0.965 & $(4.430)$ & -4.002 & (4.722) \\
\hline WEOG & -1.408 & $(3.276)$ & -1.324 & (3.345) & $-5.724^{*}$ & $(3.456)$ \\
\hline \multicolumn{7}{|l|}{ Multi-bi aid growth } \\
\hline Campaign & -0.266 & $(8.058)$ & $50.215^{* * *}$ & $(15.033)$ & $-91.455^{*}$ & $(51.564)$ \\
\hline Campaign $\times X$ & 1.790 & $(2.637)$ & $-52.535 * * *$ & $(18.481)$ & $1.079 *$ & $(0.583)$ \\
\hline $\mathrm{x}$ & -0.098 & $(0.735)$ & $16.653^{*}$ & $(9.133)$ & -0.096 & $(0.137)$ \\
\hline Financial crisis & -4.982 & $(4.271)$ & -4.448 & $(4.126)$ & -4.377 & (4.367) \\
\hline GDP growth & 0.370 & $(0.408)$ & 0.220 & $(0.397)$ & 0.188 & (0.527) \\
\hline Executive election & 3.934 & $(4.170)$ & 2.836 & (3.909) & 3.390 & (4.081) \\
\hline Left-wing government & 1.842 & $(1.822)$ & 1.479 & $(1.834)$ & 2.425 & $(1.854)$ \\
\hline Government fractionalization & $6.058^{*}$ & $(3.273)$ & 3.664 & $(3.497)$ & $7.650 * *$ & (3.356) \\
\hline Lagged aid level & $-1.917 * * *$ & $(0.460)$ & $-2.229 * * *$ & (0.479) & $-1.843 * * *$ & $(0.526)$ \\
\hline EEG & $-9.261^{*}$ & $(5.261)$ & $-8.571 *$ & $(5.122)$ & $-15.877 * * *$ & $(5.506)$ \\
\hline WEOG & -5.602 & (3.798) & $-6.630 *$ & (3.797) & $-8.900 * *$ & (3.786) \\
\hline Country-fixed effects & no & no & no & no & no & no \\
\hline Year-fixed effects & yes & yes & yes & yes & yes & yes \\
\hline$N_{B} / R_{B}^{2}$ & 590 & 0.17 & 628 & 0.18 & 594 & 0.19 \\
\hline$N_{M} / R_{M}^{2}$ & 590 & 0.19 & 628 & 0.19 & 594 & 0.18 \\
\hline$N_{M B} / R_{M B}^{2}$ & 386 & 0.23 & 388 & 0.23 & 358 & 0.22 \\
\hline$\rho_{B, M}$ & 0.080* & $(0.043)$ & 0.069 & $(0.042)$ & 0.066 & $(0.043)$ \\
\hline$\rho_{B, M B}$ & -0.065 & $(0.051)$ & -0.073 & $(0.050)$ & -0.080 & $(0.052)$ \\
\hline$\rho_{M, M B}$ & -0.007 & $(0.051)$ & -0.004 & $(0.051)$ & -0.010 & $(0.052)$ \\
\hline
\end{tabular}

Notes: System of equations estimated simultaneously with dependent variables shown in row heads. Campaign is binary and lagged by one year, $\mathrm{X}$ is the moderator in the respective column header, and Campaign $\times \mathrm{X}$ the multiplicative interaction term. Standard errors clustered on countries. Significance levels: $* \mathrm{p}<.1 * * \mathrm{p}<.05 * * * \mathrm{p}<.01$. 
Table A10. Constituency-specific effects using pooled SUR estimations.

\begin{tabular}{|c|c|c|c|c|c|c|}
\hline & $\begin{array}{l}\text { EEG } \\
(1)\end{array}$ & & $\begin{array}{l}\text { WEOG } \\
(2)\end{array}$ & & $\begin{array}{l}\text { APG } \\
(3)\end{array}$ & \\
\hline \multicolumn{7}{|l|}{ Bilateral aid growth } \\
\hline Campaign & 2.447 & (3.246) & 9.498* & $(5.364)$ & -1.946 & (3.244) \\
\hline Campaign $\times X$ & -7.736 & (8.332) & $-11.394 *$ & $(6.282)$ & $16.623^{* *}$ & (6.507) \\
\hline $\mathrm{x}$ & -2.954 & (3.189) & -0.583 & $(2.112)$ & 3.700 & (3.282) \\
\hline Financial crisis & -7.568 & $(5.001)$ & -7.609 & $(5.088)$ & -8.283 & (5.039) \\
\hline GDP growth & 0.375 & $(0.443)$ & 0.346 & $(0.426)$ & 0.298 & $(0.417)$ \\
\hline Executive election & -3.397 & (4.119) & -5.104 & $(4.096)$ & -4.430 & (3.833) \\
\hline Left-wing government & -0.405 & $(1.726)$ & -0.342 & $(1.694)$ & 0.007 & $(1.726)$ \\
\hline Government fractionalization & 0.551 & $(2.984)$ & -0.157 & $(2.957)$ & 0.918 & (3.001) \\
\hline Lagged aid level & $-2.250 * * *$ & $(0.617)$ & $-1.855^{* * *}$ & $(0.499)$ & $-2.224 * * *$ & $(0.500)$ \\
\hline \multicolumn{7}{|l|}{ Multilateral aid growth } \\
\hline Campaign & 0.749 & $(2.958)$ & 1.474 & $(5.816)$ & 0.249 & (3.064) \\
\hline Campaign $\times X$ & 0.082 & $(10.098)$ & -1.260 & (6.637) & 2.009 & (8.098) \\
\hline $\mathrm{x}$ & 3.174 & (2.398) & -2.115 & $(2.140)$ & 1.131 & (3.690) \\
\hline Financial crisis & 3.409 & $(5.716)$ & 2.901 & $(5.652)$ & 2.796 & $(5.764)$ \\
\hline GDP growth & $0.502 * *$ & $(0.250)$ & $0.489 * *$ & $(0.249)$ & $0.500 * *$ & $(0.248)$ \\
\hline Executive election & -6.308 & (3.988) & $-6.526^{*}$ & (3.797) & -6.090 & (3.874) \\
\hline Left-wing government & 1.701 & $(1.674)$ & 2.095 & $(1.618)$ & 2.125 & (1.653) \\
\hline Government fractionalization & 3.282 & (3.070) & 3.850 & (3.023) & 3.852 & (3.078) \\
\hline Lagged aid level & $-1.869 * * *$ & $(0.614)$ & $-2.048 * * *$ & $(0.579)$ & $-2.241 * * *$ & $(0.535)$ \\
\hline \multicolumn{7}{|l|}{ Multi-bi aid growth } \\
\hline Campaign & 4.782 & (3.181) & $11.277^{*}$ & $(5.864)$ & 3.950 & (3.215) \\
\hline Campaign $\times X$ & 1.794 & $(5.712)$ & -7.920 & $(6.750)$ & 7.486 & (8.881) \\
\hline $\mathrm{x}$ & -4.168 & (3.640) & -0.086 & $(2.852)$ & 4.307 & (4.143) \\
\hline Financial crisis & -6.011 & $(4.277)$ & -5.909 & $(4.404)$ & -5.094 & (4.341) \\
\hline GDP growth & 0.379 & $(0.410)$ & 0.379 & $(0.402)$ & 0.368 & (0.397) \\
\hline Executive election & 4.111 & (4.335) & 3.570 & $(4.261)$ & 3.774 & $(4.086)$ \\
\hline Left-wing government & 1.378 & $(1.786)$ & 1.305 & $(1.764)$ & 1.634 & (1.790) \\
\hline Government fractionalization & 4.703 & (3.111) & 4.380 & (3.110) & $5.436 *$ & (3.238) \\
\hline Lagged aid level & $-1.828 * * *$ & $(0.453)$ & $-1.644 * * *$ & $(0.421)$ & $-1.735^{* * *}$ & $(0.409)$ \\
\hline Country-fixed effects & no & no & no & no & no & no \\
\hline Year-fixed effects & yes & yes & yes & yes & yes & yes \\
\hline$N_{B} / R_{B}^{2}$ & 481 & 0.11 & 481 & 0.12 & 481 & 0.13 \\
\hline$N_{M} / R_{M}^{2}$ & 481 & 0.12 & 481 & 0.12 & 481 & 0.11 \\
\hline$N_{M B} / R_{M B}^{2}$ & 383 & 0.15 & 383 & 0.16 & 383 & 0.16 \\
\hline$\rho_{B, M}$ & 0.004 & $(0.047)$ & -0.003 & $(0.047)$ & -0.001 & $(0.047)$ \\
\hline$\rho_{B, M B}$ & 0.040 & $(0.052)$ & 0.031 & $(0.052)$ & 0.027 & $(0.052)$ \\
\hline$\rho_{M, M B}$ & $0.110 * *$ & $(0.051)$ & $0.105^{* *}$ & $(0.051)$ & $0.108^{* *}$ & $(0.051)$ \\
\hline
\end{tabular}

Notes: System of equations estimated simultaneously with dependent variables shown in row heads. Campaign is binary and lagged by one year, $\mathrm{X}$ is the moderator in the respective column header, and Campaign $\times \mathrm{X}$ the multiplicative interaction term. Standard errors clustered on countries. Significance levels: ${ }^{*} p<.1 * * p<.05 * * * p<.01$. 
Appendix B. Coding protocol and illustrative examples.

\section{B1. A Glance at the Raw Data}

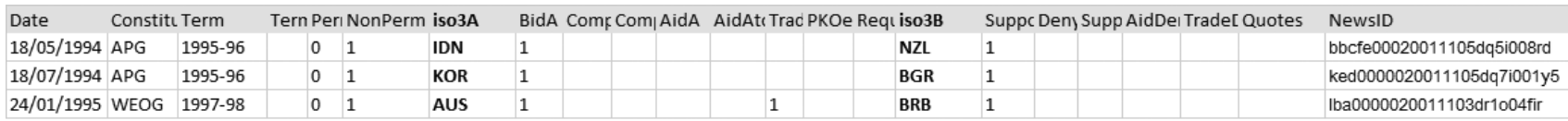

Description of the variables (most relevant variables highlighted in bold font):

- Date: exact date of media report

- Constituency: name of the UN constituency

- Term: term for which donor seeks UNSC membership (if not mentioned, then this value was imputed from other sources)

- Permanent: 1 if donor is seeking permanent UNSC membership (observations with Permanent $=1$ discarded)

- NonPerm: 1 if donor is seeking non-permanent UNSC membership

- iso3A: country code of the donor seeking UNSC seat

- BidA: 1 if press report states that donor seeks support for its UNSC candidature (observations with BidA $=0$ discarded)

- Comp1: country code of first competitor also vying for UNSC seat in the same term if the media report mentions it

- Comp2: country code of any second competitor if media report mentions it (these variables are not used as they are likely incomplete and other sources should be used)

- AidA: 1 if donor is reported to commit to aid increase to unspecified recipients in the same media report

- AidAtoB: 1 if donor is reported to commit aid increase to specified recipient (iso3B) in the same media report

- TradeAgreement: 1 if donor is reported to promise better trade relations with specified recipient (iso3B) in the same media report

- PKOengage: 1 if donor is reported to commit more engagement in UN peacekeeping in the same report

- RequestSupport: 1 if donor solicits support for its UNSC candidature from (un)specified recipient(s)

- iso3B: country code of supporting country

- SupportA: 1 if media report mentions iso3B supporting UNSC candidature for iso3A

- DenySupport: 1 if media report mentions iso3B denying support for UNSC candidature of iso3A

- SupportAB: 1 if report mentions commitment of mutual support for UNSC bids between iso3A and iso3B

- AidDemanded: 1 if report mentions iso3B asking for increased development cooperation from iso3A

- TradeDemanded: 1 if the report mentions iso3B asking for increased trade cooperation with iso3A

- Quotes: Any key quotes from the article; also codes exhaustively for instances of support for candidacies in other international venues

- NewsID: Factiva news ID

- Media report (derived variable): 1 if document is a relevant media report (NonPerm $=1$ and BidA $=1$ ) in which the donor requests support or receives it (RequestSupport $=1$, SupportA $=1$, or SupportAB $=1$ ). Used for aggregation to the donor-year level and then called Campaigns.

\section{B2. The Data Collection Process}

A media report is relevant in the context of my research question if it contains explicit mentioning of the aspiration for temporary UNSC membership of a given country. A media report is irrelevant under any of the following conditions: 1) the report type is an opinion piece that does not present any new information previously coded; 2 ) the article discusses institutional reform of the UNSC; 3 ) a country vies for permanent membership in the UNSC.

To identify as many relevant source documents as possible, I tried several combinations of search strings and found the following to yield the best results in terms of covering many relevant media reports while discarding the irrelevant ones (based on a glance at the first hundred hits):

united nations security council near7 (candidacy or candidate or candidature or non-permanent member not permanent or temporary seat or membership or election or campaign or competition or bid) near5 (win or won or lose or lost or announce or vote or elect or select or choose or chosen or assume or support or assist or encourage)

Further search options in the Factiva menu included:

- English language

- Duplicates not included (if one event is reported by several newswires) 


\section{B3. The Coding Process: An Illustrative Example}

The following media report is one document in the entire Factiva dataset (which contains 1,706 documents covering the 1994-2016 period). Factiva has highlighted the main search terms in yellow. In addition, I have underlined text passages that are used to code the variables in the campaigning spreadsheet.

\section{BBBC}

President Museveni urges Icelandic entrepreneurs to invest in Uganda

332 words

19 September 2008 15:57

BBC Monitoring Africa BBCAP English

(c) 2008 The British Broadcasting Corporation. All Rights Reserved. No material may be reproduced except with the express permission of The British Broadcasting Corporation.

Text of report by state-run Uganda Broadcasting Corporation (UBC) Radio on 19 September

[Presenter] President Yoweri Museveni has invited entrepreneurs in Iceland to invest in priority areas of the Ugandan economy such as infrastructural development, harnessing energy and agro-processing for the export market. He is in Iceland on a state visit.

Mr Museveni thanked Iceland for development and humanitarian assistance Iceland continues to extend to Uganda, particularly in adult literacy, energy, fisheries and scientific research to raise household income, especially among the rural poor.

He commended Iceland for her great strides in geothermal energy, hydropower, ICT and fisheries, adding that Uganda would like to share this experience. Mr Museveni said he was impressed by the achievements of Iceland in social, economic and political transformation, and said his government aims to transform Uganda from a peasant society to an industrial nation.

He said Uganda will support Iceland's candidature for the United Nations Security Council slot, saying Uganda hopes to also serve on the same council in future.

Mr Museveni invited President Grimsson to visit Uganda, which was accepted.

President Olafur Grimsson saluted the people of Uganda and hoped that the growing cooperation between the two countries would become a model. He said President Museveni's visit was a demonstration of the desired collaboration in geothermal resources, fishing and ICT, where Iceland has a comparative advantage. He assured Mr Museveni that Iceland would cooperate with Uganda.

Grimsson has said Africans, through the Organization of African Unity, the precursor to the African Union, supported the Icelandic cause for freedom and even send a delegation of solidarity to Iceland in support of the struggle for independence.

Grimsson, said in welcoming President Museveni and his delegation, he was paying tribute to the vision of the African leaders, who decades ago, understood that solidarity across oceans, was essential in building a progressive global community.

Source: UBC Radio, Kampala, in English 0400 gmt 19 sep 08

Document BBCAP00020080919e49j000dx 
The following variables are affected by the information in this media report:

\begin{tabular}{|c|c|c|c|c|c|c|c|c|c|c|c|}
\hline Date & Constituency & Term & Permanent & $\begin{array}{l}\text { Non } \\
\text { Perm }\end{array}$ & iso3A & $\begin{array}{l}\text { Aid } \\
\text { AtoB }\end{array}$ & BidA & iso3B & SupportA & SupportAB & $\begin{array}{c}\text { Trade } \\
\text { Demanded }\end{array}$ \\
\hline $19 / 09 / 2008$ & WEOG & 2009-10 & 0 & 1 & ISL & 0 & 1 & UGA & 1 & 1 & 1 \\
\hline
\end{tabular}

Iceland (iso3a = "ISL") vies for a non-permanent UNSC seat (NonPerm=1 and BidA = 1), supported by Uganda (iso3b = "UGA"). Uganda publicly declares to support this candidature (SupportA =1). It is also implicit in the news report that Uganda would like to intensify commercial links with Iceland in this context (TradeDemanded $=1$ ) and is expecting support for its own future candidacy (SupportAB =1). However, Iceland does not promise any new aid $($ AidAtoB $=0)$, while reaffirming its ongoing development support.

\section{B4. Data Preparation for Analysis}

To allow for country-year panel data analysis, the information in the media reports needs to be aggregated. The variable Media Report covers both a statement of support from another country as well as unilateral solicitation of support for UNSC candidature by a donor. I aggregate the number of lines (representing the number of media reports) for each unique country-year pair to obtain the (untransformed) measure Campaigns. The main analysis relies on the dummy variable 1 (Campaigns $>0$ ).

\section{B5. Descriptive Statistics}

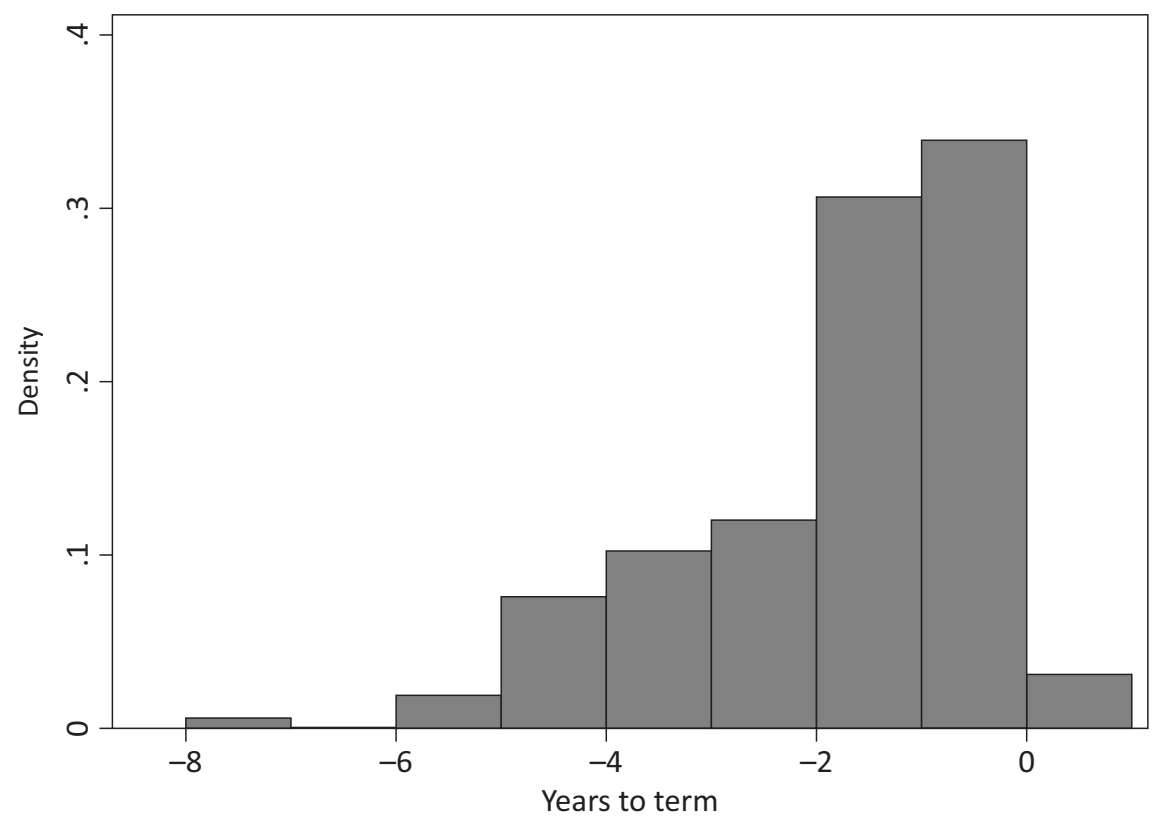

Figure B1. Distribution of campaigning events relative to the envisaged term. Note: The sample includes media reports on the same donors on which the main analysis is based. 